\title{
Os primórdios da organização do espaço territorial e da vila cearense - algumas notas
}

\begin{abstract}
Clovis Ramiro Jucá Neto ${ }^{1}$
RESUMO: $\bigcirc$ presente artigo apresenta, em grandes linhas, a ação empreendida pelos agentes econômicos, pelos representantes da lgreja e do Estado português na organização do espaço da capitania do Ceará no século XVIII. Para uma melhor capitalização da economia pecuarista, o Estado lusitano fundou vilas em lugares estratégicos onde primeiramente se fixaram os sesmeiros e a lgreja. Não houve razão nem justificativa econômica e geopolítica que demandasse investimentos técnico e de capital por parte dos portugueses na plena adequação dos condicionantes locais às diretrizes urbanísticas lusitanas. Em face da ocupação tardia, o artigo aborda ainda a também tardia representação cartográfica, como expressão da posição secundária dos interesses lusitanos em relação a uma melhor apreensão da região.

PALAVRAS-CHAVE: Capitania do Ceará. Agentes econômicos. Igreja. Estado português. Diretrizes urbanísticas. Cartografia.

ABSTRACT: This paper presents, in outline, the action taken by economic agents, representatives of the Church and the Portuguese State in organizing the space of the Captaincy of Ceara in the eighteenth century. The Portuguese State founded towns in strategic locations for better capitalization of the cattle breeder economy, where first settled sesmeiros and the Church. There was no reason or justification of geopolitical nature that demanded technical and financial investments by the Portuguese in the full adequacy of the local conditions to Portuguese urban guidelines. In the face of the late occupation, the article also discusses the late cartographic representation as expressing the lack of interests of the Portuguese administration in relation to a fuller understanding of the region.

KEYWORDS: Captaincy of Ceará. Economic agents. Church. Portuguese State. Urban guidelines. Cartography.
\end{abstract}

\begin{abstract}
1. Docente do Departamento de Arquitetura e Urbanismo da Universidade Federal do Ceará. E-mail: <clovisj@uol. com.br>.
\end{abstract}


2. Em 30 de junho de 1698 , uma provisão régia, já mandava que os pecuaristas estabelecidos desde Itapuã até o Rio Vermelho, na Bahia, levassem seus gados para o interior dentro do prazo de um mês, pois era grande o prejuízo dos lavradores por conta do gado que invadia $\mathrm{e}$ destruía os roçados; cf. José Alípio Goulart (1963, p. 19). Em 1701, a Coroa determinou um afastamento para o criatório de, no mínimo, dez léguas a partir da área de plantio da cana; cf. Roberto C. Simonsen (1978, p.151); e José Alípio Goulart (1965, p. 17). Em 30 de janeiro de 1705 , o governador do Brasil,Dom Rodrigo Costa, deu prosseguimento ao cumprimento das determinações régias, proibindo a criação de gado no termo da vila de Boipeba, também na Bahia; ver D. Rodrigo Costa (1939, p.306),

3."Quando tudo era meio natural, o homem escolhia da natureza aquelas suas partes ou aspectos considerados fundamentais ao exercício da vida, valorizando, diferentemente, segundo os lugares e as culturas, essas condições naturais que constituíam a base material da existência do grupo." Cf. Milton Santos (1999, p.187)

4. Ver João Capistrano de Abreu (1998).

5. Ver Joaquim Alves (2003).

6.Ver Pedro Puntoni (2002)

7. Sobre o assunto, ver, além de Pedro Puntoni (2002), os artigos de Carlos Studart Filho $(1959,1961)$ objetivo do texto é apresentar algumas notas sobre o papel dos vaqueiros, dos boiadeiros, dos sesmeiros, da população indígena e dos representantes da lgreja e do Estado português na organização do espaço cearense. De imediato, afirmamos que o espaço socialmente modificado do Ceará setecentista não pode ser apreendido simplesmente através das especificidades das ações dos envolvidos na organização espacial ou seja, através de suas singularidades, tampouco as ações de cada agente devem ser compreendidas unicamente como aspectos particulares das ações dos demais. $\bigcirc$ espaço da capitania manifesta-se como uma síntese onde dialeticamente interagem as múltiplas ações dos diversos agentes. Somente como estratégia metodológica, a síntese é decomposta, e as atividades daqueles ligados à atividade da pecuária, da Igreja e do Estado lusitano são apresentadas em tópicos diferenciados.

\section{A ocupação do território e os agentes econômicos}

No final do século XVII e nos primeiros anos do século XVIII, após as decisões régias portuguesas ${ }^{2}$ de no Brasil reservar a faixa litorânea nordestina unicamente para a produção do açúcar, os criadores de gado, com suas boiadas, partiram em direção à capitania do Maranhão em busca de novas pastagens. A expulsão da pecuária implicou uma primeira separação geoeconômica no Nordeste brasileiro. Enquanto a atividade açucareira desenvolveu-se no próximo e rico litoral, ao criatório restou o longínquo e pobre sertão.

Cruzando o Ceará no decorrer do Setecentos, a economia pecuarista, a despeito de sua baixa produtividade e pequena rentabilidade, atribuiu sentido à ocupação e deu forma e conteúdo à capitania.

A instalação dos boiadeiros aliada à da lgreja - domesticando a população indígena que resistia à expansão do criatório - e à participação do Estado português - com a fundação das vilas significou a possibilidade de capitalização em torno da atividade comercial da pecuária.

O território cearense - como meio natural e base material da existência - não se apresentou nada favorável à fixação dos primeiros conquistadores ${ }^{3}$. A conquista aconteceu de forma bastante violenta. Somente passado o medo da região, os desbravadores construíram suas fazendas e levaram suas famílias para o sertão ${ }^{4}$. $\bigcirc$ medo era resultante da adversidade climática e da resistência indígena. Durante o século XVIII, a seca manifestou-se por cinco vezes por todo o Nordeste: 1721-1725; 1736-1737; 1745-1746; 1777-1778; e 1791-17935. A Guerra dos Bárbaros 6 foi apenas um dos capítulos da sangrenta conquista 7 . Além do embate com os índios, as brigas entre os sesmeiros também coloriram de sangue a colonização.

Toda a ocupação e a fixação encontraram apoio no sistema de sesmarias. Os primeiros sesmeiros não só foram os primeiros donos da terra como 
também ocuparam postos militares e funções de ordenanças nas câmaras das vilas fundadas ${ }^{8}$.

A análise das justificativas das concessões demonstra que a atividade criatória foi a principal responsável pela ocupação da capitania. Das 2472 datas solicitadas entre 1679 e 1824, 90,85\% tinham como justificativa a necessidade de terra para a pecuária?.

\section{A fazenda de gado}

Já na primeira metade do século XVIII, a fazenda de gado dispersa no sertão sediou o povoamento. Foi a sede das sesmarias, da unidade familiar, da atividade produtiva e também onde se encontraram as condições propícias para os primeiros sinais de acumulação de renda no sertão. Além disso, foi sede da vida política local, de toda autarquia sertaneja e suas famílias, com poderes quase que absolutos, e da rede de mandos e desmandos que pautou a organização territorial. Cumpriu, ainda, o papel de defesa diante da população indígena ou perante outros sesmeiros na luta pela posse das terras.

Em seu espaço, presenciou-se o processo de miscigenação e aculturação entre índios e brancos, de fundamental importância para a formação da sociedade cearense.

Dentro das sesmarias, as fazendas localizavam-se em pontos estratégicos, muitas vezes em locais elevados e sempre próximos a um riacho ou rio.

Todo o programa das fazendas estava diretamente associado às necessidades produtivas da economia. Além da sede, havia o curral e cercados para a agricultura; em algumas, pequenos açudes e, muito raramente, uma capela.

A tecnologia empregada era a própria expressão do meio físico ante o novo sistema-mundo mercantil que se instalava nas ribeiras do sertão cearense.

Na casa do Umbuzeiro (Aiuaba, CE) do século XVIII, pode-se observar o emprego da dita tecnologia os alicerces eram de alvenaria de pedra, as paredes eram de taipa de sopapo ${ }^{10}$, e o piso era revestido com ladrilhos de barro cozido ou de terra batida. A coberta era de quatro águas com a forma piramidal, as telhas de barro e o madeiramento eram aparentes, os vãos das esquadrias possuíam rasgos normais às paredes, não havia ornatos, as vergas eram retas, e as esquadrias feitas com tabuado comprido com junta seca' ${ }^{11}$ (Figura 1).

A técnica usada na construção era, portanto, regida pelo tempo social do criatório, marcado pela escassez de mão de obra, pela urgência da fixação, em um meio natural plasmado pela terra rachada, pela agressividade climática, pela falta de chuva, pela rara presença de pastagens, pela quase inexistência de rios perenes.

A técnica empregada é o indicativo tanto das reais possibilidades, durante o século XVIII, de intervenção humana no meio físico cearense como das
8. Ver Gabriel Parente Nogueira (2010).

9. Cf. Francisco José Pinheiro (2008, p. 23).

10.A taipa de sopapo consiste na elaboração de um varal longitudinal, onde se preenchem os espaços com argila e areia; cf. Sylvio de Vasconcelos (1970, p.2).

11. Bezerra identifica os mesmos sistemas construtivos nas fazendas do Inhamuns; cf. Maria do Carmo Lima Bezerra (1984, p.59). 


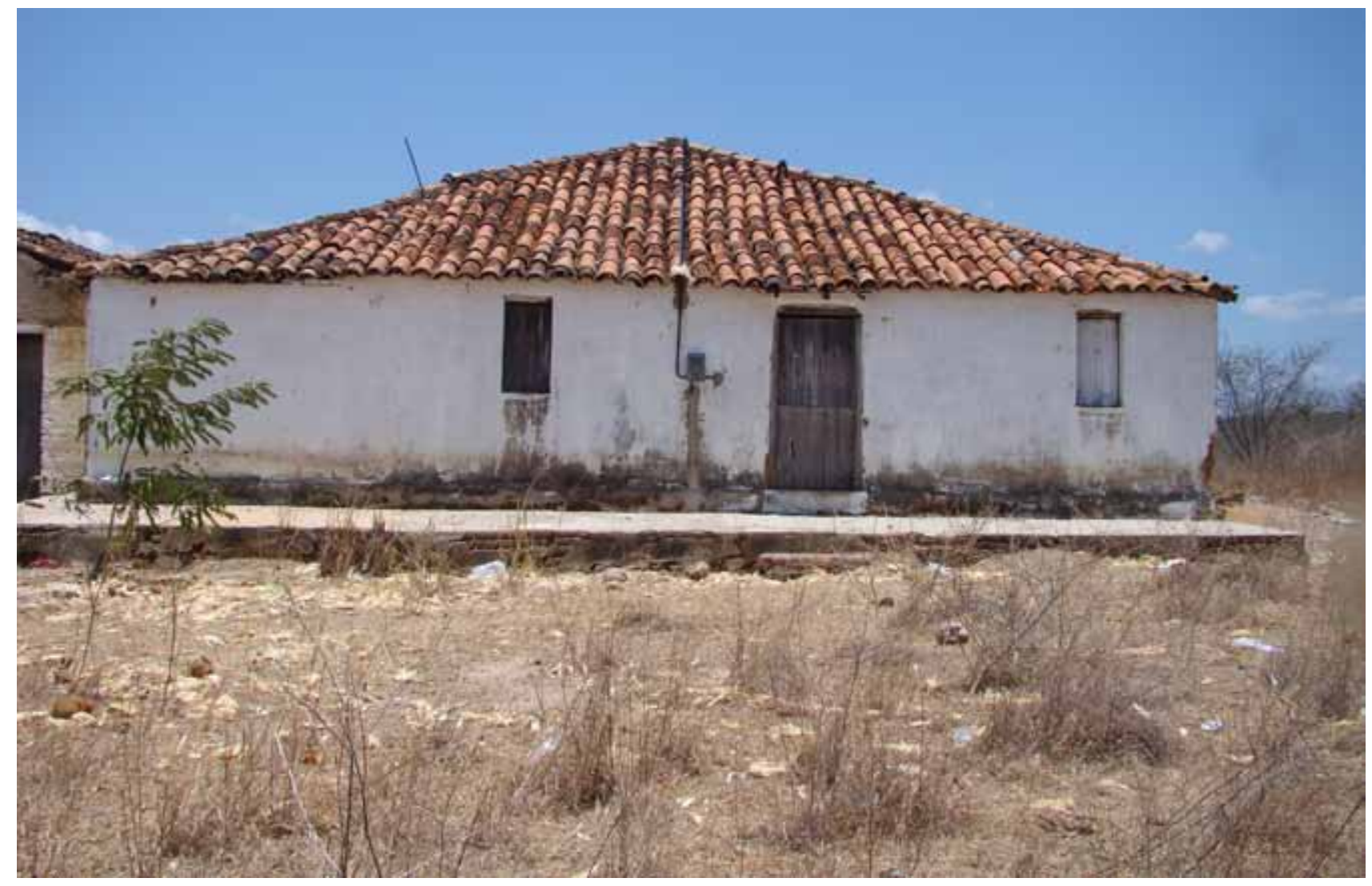

Figura 1 - Casa do Umbuzeiro, século XVIII. Município de Aivaba (CE). Fonte: Acervo Clovis Jucá.

12. Milton Santos (1999, p. 188). [na edição mais recent.

13. Idem, ibidem. determinações sociais que levaram o homem a fixar-se em um território marcado pela agressividade do meio natural.

A robustez e a ausência de ornatos das construções setecentistas cearenses são nada mais que a dimensão físico-social do possível nesse lugar da intervenção mergulhada "no determinismo" de seu "funcionamento"12. Ou seja, as motivações de uso aliadas às características do meio natural, com suas características locais, eram regidas pelos condicionantes sociais que envolviam a prática da pecuária.

O uso e a alteração do meio natural cearense ocorreram sem grandes transformações do meio herdado. Nesses primeiros momentos - como afirma Milton Santos ao referir-se ao "meio natural" antes de sua substituição por um "instrumentalizado", "as técnicas e o trabalho se casavam com as dádivas da natureza, com a qual se relacionavam sem outra mediação"13; ou, no caso específico do Ceará, se casavam com as limitações do meio.

Os diversos agentes envolvidos nos primórdios da apropriação e alteração do espaço cearense foram os criadores das técnicas possíveis, expressas na construção das primeiras fazendas de gado, no contexto físico social dos 
momentos iniciais da fixação. Se, por um lado, a intervenção no meio natural dificilmente ultrapassava as possibilidades das restritivas matérias do sertão e da mão de obra adestrada às limitações presentes, por outro, extrapolava esses condicionantes limitadores, pela urgência do funcionamento da "civilização do couro", da ação da conquista, do trabalho cotidiano junto às boiadas, da necessidade da fixação, do descanso, da pausa do trabalho.

As fazendas de gado espalhadas pelo sertão deram origem a alguns núcleos, onde mais tarde foi fundada a maioria das vilas de brancos na capitania do Ceará. No decorrer do Setecentos, estas, lentamente, em conjunto com as vilas de índios alteraram a dispersão reinante no litoral e no sertão cearense.

A ocupação do território e a lgreja

Durante o século XVIII, com os primeiros desbravadores, a lgreja se fixou no território dando prosseguimento ao trabalho de catequese. Embora tardiamente, o processo de conversão da capitania não foi diferente daquele empreendido em outras regiões brasileiras, antecedendo o poder civil. As tentativas de conversão ocorreram de forma itinerante, não constituindo grandes ajuntamentos, como nas missões estabelecidas na região Sul do Brasil. É possível presumir que, ao contrário da atividade produtiva do açúcar, concentradora de mão de obra, a atividade extensiva da pecuária e sua extrema dispersão tenham dificultado a instalação da lgreja. Mas, além daqueles que se fixaram temporariamente, vários religiosos foram proprietários de sesmarias ou estavam "integrados em congregações beneficiadas com doações de terras" 14 . Assim o território cearense foi pontuado por ermidas, capelas, aldeamentos pequenos e efêmeros que tiveram à frente, na maioria das vezes, padres seculares, os Clérigos do Hábito de São Pedro.

Já o projeto jesuítico na capitania do Ceará prendeu-se ao surgimento de algumas pequenas "missões anteriormente estabelecidas pelos inacianos em Parangaba, Caucaia e Paupina, nas proximidades da Serra da Ibiapaba, [...] da Serra de Baturité [...] dos Cariris-Novos", e na instalação do Real Hospício ${ }^{15}$ jesuítico em Aquiraz. As missões de Parangaba, Caucaia, Paupina, das serras da Ibiapaba, de Baturité e dos Cariris Novos foram transformadas em vilas no reinado de D. José I. Os novos topônimos impostos pelas autoridades portuguesas foram, respectivamente, os de Arronches (atual Parangaba), Soure (atual Caucaia), Messejana, Vila Viçosa Real, Monte-mor o Novo da América (atual Baturité) e Vila Real do Crato. As missões dos Tremenbés, no rio Aracati-Mirim, e a dos Pacajús, no rio Choró, tornaram-se respectivamente Almofala e Monte-mor o Velho da América (atual Pacajus), mas permaneceram como simples povoados ${ }^{16}$.

Como afirma Bueno ${ }^{17}$, durante o período colonial as instâncias de poder organizavam-se, hierarquicamente, "em instituições irradiadas a partir das 'cidades reais'". Essas instituições "administrativas, jurídicas e eclesiásticas sobrepunham seus
14. Cf. Geraldo da Silva Nobre (1986, p.246).

15. Segundo Serafim Leite, "entende-se por Hospício uma Casa ou Residência grande, cabeça de toda Missão, diferente das casas das $\mathrm{Al}$ deias. A ela se acolheriam os missionários das Aldeias para repousar, de vez em quando; e dela, os missionários, que habitassem de assento, iriam fazer missões às Aldeias e ao sertão. Seria também uma como enfermaria geral dos missionários onde se recolhessem os doentes ou alquebrados pela idade. A este conceito primitivo acresceu, mais tarde outro, de estudos, vindo a ser êste Hospício o primeiro Seminário e o primeiro estabelecimento oficial de Latim e Humanidades no Ceará"; cf. Serafim Soares Leite (1943, p. 73).

16. Cf. Geraldo da Silva Nobre (1986, p. 242).

17. Ver Beatriz P. Bueno (2009). 
18. Idem, p. 252.

19. Como afirma Murillo Marx, a institucionalização de "tantas e tão dispersas comunidades" se dava pela oficialização das ermidas, "de sua capelinha visitada por um cura, pela sua elevação um dia a matriz, elevação que significava a ascensão de toda uma região inóspita [...] ao novo status de paróquia ou freguesia". Ainda de acordo com o autor, o que se obtinha não era somente o acesso à assistência religiosa, mas o "reconhecimento da comunidade de fato $e$ de direito perante a igreja oficial, portanto perante o próprio Estado"; cf. Murillo Marx (1991, p.18). Sobre o mesmo processo em Minas Gerais, ver Cláudia Damasceno Fonseca (2001, p.773)

20. Sobre a "conversão" dos sertões mineiros, cf. Cláudia Damasceno Fonseca (2001, p. 773).

21. As léguas são medidas de comprimentos longos variados, que, no mar, na ausência de pontos fixos terrestres visíveis, dependem do grau (astronômico) do meridiano terrestre considerado ao fazer a medição. A légua de 18 ao grau, por exemplo, corresponde a cerca de $6172 \mathrm{~m}$. Quando o grau não é especificado, costuma corresponder à légua "métrica" terrestre, que pode "valer", por exemplo, 2500 braças, isto é, $5,5 \mathrm{~km}$; ou, no periodo colonial brasileiro, 3 mil braças, isto é, $6,6 \mathrm{~km}$. Meia légua é pouco mais de $3 \mathrm{~km}$.

22. Cf. Limério Moreira da Rocha (2001, p. 78).

23. Cf. Geraldo da Silva Nobre (1980, p. 231).

24. Idem, ibidem.

25. Cf. Limério Moreira da Rocha (2001, p. 79),

26. Segundo o padre Serafim Soares Leite (1943, p. 76), o jesuíta João Guinzel é o territórios no espaço". Eram "tentáculos metropolitanos na distante 'Conquista', cumprindo papéis distintos"18 na lógica da ocupação territorial.

A rede eclesiástica cearense precedeu a rede civil mas, em termos jurídicos, ficava submetida a ela, assim como ocorreu no restante do território brasileiro. Algumas ermidas espalhadas pelo sertão, após a autorização do bispado de Pernambuco, foram transformadas em capelas curadas, visitadas pelo capelão residente da capitania e dependentes das paróquias mais próximas. Com o tempo, no entorno de algumas dessas capelas se organizaram pequenas povoações, alterando a dispersão reinante, vagarosamente, pela materialidade construída dos incipientes núcleos e a institucionalização dos mesmos ${ }^{19}$. Com o aumento do número de "pessoas de desobriga" ou o crescimento do núcleo adstrito às capelas, o bispo pernambucano era solicitado para a criação de uma paróquia, ou freguesia. Se colada, a freguesia teria um vigário dedicado unicamente a ela, remunerado pela Coroa ${ }^{20}$.

\section{Sobre o lugar de alguns primeiros aldeamentos no Ceará}

Até o ano de 1700, identificamos quatro aldeamentos sob os cuidados dos Clérigos do Hábito de São Pedro; além da missão dos jesuítas na serra da Ibiapaba, definitivamente instalada por volta de 1695. Não nos foi possível determinar suas durações. Dos quatro, dois estavam localizados na Ribeira do Jaguaribe e dois nas proximidades da futura vila de Fortaleza. Em 1696, os índios paiacus foram reunidos na Aldeia de Nossa Senhora da Madre de Deus (Aldeia Velha), a meia légua ${ }^{21}$ do monte Arerê, atual Itaiçaba, na Ribeira do Jaguaribe, sob a ação do clérigo João da Costa 22 . Em 1697, os índios jaguaribaras e anacés foram aldeados em Parnamirim, a sete léguas de Fortaleza, pelo clérigo João Leite de Aguiar ${ }^{23}$. No ano seguinte, em 1698, Nobre faz referência a um aldeamento nas proximidades da futura vila de Nossa Senhora da Assumpção, sob a atenção do também clérigo João Alvares da Encarnação ${ }^{24}$. Em 1699, o clérigo padre João da Costa cria um novo aldeamento (Aldeia Nova) na Aldeia de Nossa Senhora da Montanha, localizada a 14 léguas da antiga Aldeia Velha.

Também no início do século XVIII, identificamos a presença de padres da Companhia de Jesus em missão na Ribeira do Jaguaribe. Segundo Rocha ${ }^{25}$, em 1700, o jesuíta João Guinzel ${ }^{26}$ reuniu índios baiacus na Missão de Nossa Senhora da Anunciada ou Anunciação ${ }^{27}$ (Aldeia do Jaguaribe), nas proximidades da atual cidade de Tabuleiro do Norte ${ }^{28}$.

Em 1702, de acordo com Nobre ${ }^{29}$, estando em missão pelo sul do Ceará, o padre João de Matos Serra, vigário colado da vila de Aquiraz $^{30}$, fundou - Arraial Novo, sob a invocação de Nossa Senhora do Ó, onde hoje é a cidade do Icó, e aí aldeiou os índios icós.

Henrique Luís Pereira Freire de Andrada, governador da capitania de Pernambuco, escreveu ao rei D. João $V$, em 173931, apresentando uma relação das missões e aldeias da capitania pernambucana. Na capitania do Ceará, anexa à capitania de Pernambuco, foram inventariados treze aldeamentos (Tabela 1). 


\section{As primeiras capelas}

Em alguns casos, após o erguimento das fazendas de gado, os sesmeiros requeriam permissão ao bispado de Pernambuco ${ }^{32}$ para construção de uma ermida, onde poderiam ouvir as missas celebradas por capelães. A permissão significava assistência religiosa. As ermidas eram construídas em terras doadas ${ }^{33}$ por um ou mais de um proprietário de terra, contribuindo para a formação do patrimônio eclesiástico na capitania cearense. Juntamente com a fixação dos boiadeiros, a lgreja reafirmava, assim, sua presença no território instalando-se nas terras oferecidas.

Tabela 1

Relação das missões e aldeias do Ceará (1739)

\begin{tabular}{|c|c|c|c|c|}
\hline $\begin{array}{c}\text { Nome da Missão ou } \\
\text { Aldeia }\end{array}$ & $\begin{array}{l}\text { (Ordem ou } \\
\text { Irmandade) }\end{array}$ & $\begin{array}{l}\text { Religioso } \\
\text { (padre, frei } \\
\text { ou clérigo) }\end{array}$ & $\begin{array}{l}\text { Lugar } \\
\text { (topônimo) }\end{array}$ & Índios \\
\hline Missão da lbiapaba & Jesuíta & ni & Viçosa & $\begin{array}{c}\text { tabajaras, anassés e } \\
\text { outros (É assim que } \\
\text { se encontra do doc } \\
\text { histórico !!!) }\end{array}$ \\
\hline Aldeia do Miranda & capuchinho & $\begin{array}{l}\text { Francisco Carlos } \\
\text { Maria de Ferrara }\end{array}$ & Crato & $\begin{array}{c}\text { carius, assus, } \\
\text { calabaças e quixeloz }\end{array}$ \\
\hline Aldeia do Banabuiú & clérigo & Zechiel Gameyro & $\begin{array}{c}\text { Serra da } \\
\text { Uruburetama }\end{array}$ & $\begin{array}{l}\text { genipapos } \\
\text { e canindés }\end{array}$ \\
\hline Vila de Fortaleza & - & - & Fortaleza & anassés \\
\hline Aldeia dos Jaguaribaras & clérigo & ni & Citio Cascavel & jaguaribaras \\
\hline Aldeia dos Payacus & clérigo & Luiz Ferreira & $\begin{array}{l}\text { Taboleyro } \\
\text { do Cascavel }\end{array}$ & paiacus e assus \\
\hline Aldeia dos Jucazes & clérigo & $\begin{array}{l}\text { Antonio Nunes } \\
\text { Cabral }\end{array}$ & $\begin{array}{c}\text { Jucás } \\
\text { (São Mateus) }\end{array}$ & jucás \\
\hline Aldeia dos Tarabembés & Jesuíta & ni & Almofala & tremembés \\
\hline Aldeia de Parnamirim & Jesuíta & ni & Eusébio & tremenbés \\
\hline Aldeia de Paupina & Jesuíta & ni & Messejana & tremenbés \\
\hline Aldeia Nova & Jesuíta & ni & ni & tremenbés \\
\hline Aldeia de Parangaba & Jesuíta & ni & Parangaba & tremenbés \\
\hline Aldeia de Guacaya & Jesuíta & ni & Caucaia & tremenbés \\
\hline
\end{tabular}

Convenções: -: inexistente; ni: não identificados. [é peciso discriminar os outros - se são vários; se são ni:não identificadosenocasodoslocaisedosíndiosfaltantes, colocar, respectivamente, sítioaproximado; ese sãováriosouni] Fonte: AHU_ACL_CU_015. Cx. 55. D. 4767. Arquivo Histórico Ultramarino. Projeto Resgate.

Nobre assevera que, muito provavelmente, "excluídas a do Forte de Nossa Senhora da Assumpção e as das aldeias dos missionários"34, a capela mesmo padre jesuíta João Guedes, um dos fundadores do Real Hospício de Aquiraz no Ceará.

27. Carlos Studart Filho escreveu que, em 1700, "o padre João Guedes, com ajuda do padre Vicente Vieira, fundou a Aldeia de Nossa Senhora daAnunciada, onde reuniu os Baiacus do Jaguaribe"; apud Geraldo da Silva Nobre (1980, p. 235). Os padres João Guedes e Vicente Vieira pertenciam à Companhia de Jesus; ver também Serafim Soares Leite (1943, p.94).

28. [A] 10 léguas acima do Forte de São Francisco Xavier [...] a poucos quilômetros ao poente, da atual cidade de Tabuleiro do Norte, nas proximidades do Rio Jaguaribe, e do lado nascente, de onde hoje se situa São João do Jaguaribe, no local onde, ainda nos dias atuais, existe o lugar denominado Aldeia Velha, com poucas casas." Cf. Limério Moreira da Rocha (2001, p. 79).

29. Cf. Geraldo da Silva Nobre (1980, p. 238).

30. Cf. Guilherme Ch. Studart (1923, p. 303).

31. Ver AHU_ACL_CU_015. Cx. 55. D. 4767, Arquivo Histórico Ultramarino, Lisboa. Projeto Resgate.

32. As paróquias do Ceará eram subordinadas ao Bispado de Pernambuco e este, ao Arcebispado da Bahia, criado em 1676; cf. Limério Moreira da Rocha (2001, p. 112).Ainda segundo esse autor, "por divergência, quer no temporal quer no eclesiástico, entre o governo da Bahia e de Pernambuco, o citado Bispado, de início, preferira permanecer subalterno ao Patriarcado de Lisboa, como antes, objetivando livrar-se das regras expedidas pelo Arcebispado baiano, consideradas injustas, como por exemplo, as instituídas em 1707 pelo então Arcebispo da Bahia D. Sebastião Monteiro da Vide, 
denominadas 'Constituições Primeiras do Arcebispado da Bahia', excessivamente severas e pautadas ainda nas determinações do Concílio de Trento". O Bispado de Pernambuco somente começou a aceitar inteiramente as Constituições do Arcebispado em 1721; cf. idem, p.113.

33. Em troca da doação de "terras para o santo, seu patrimônio ou da sua capela", eram rezadas missas para $o$ doador e sua família, em vida e após a morte; cf. Murillo Marx (1991, p. 26).

34. Cf. Geraldo da Silva Nobre (1980, p.242).

\section{Idem, ibidem.}

36. Ver AHU_ACL_CU_017. Cx. 12. D. 693, Arquivo Histórico Ultramarino, Lisboa. Projeto Resgate.

37. Ibidem.

38. Geraldo da Silva Nobre (1980, p.246) dedicada à Nossa Senhora do Ó cujo patrimônio fora doado pela família Montes na ribeira do rio Salgado, no lugar da futura matriz de Nossa Senhora da Expectação do lcó, foi a primeira a erigir-se no Ceará. A Carta Régia fundacional da Vila de Nossa Senhora da Expectação do Icó, de 1736, determinou a criação de uma "nova Villa no Icó junto aonde se acha a lgreja Matriz" 35.

Por volta de 1793, Manuel da Cunha Pereira, o capitão comandante da Ribeira do Jaguaribe, pediu licença à rainha D. Maria I para edificar uma ermida em homenagem a Nossa Senhora das Dores, em sua fazenda chamada Boqueirão, localizada na freguesia das Russas ${ }^{36}$. $\bigcirc$ documento expressa os procedimentos que provavelmente todos os detentores de terra, durante o século XVIII, deviam ter seguido ao requerer ao bispado de Pernambuco a construção das primeiras capelas no território cearense. A requisição implicava na doação de terras para o orago correspondente à igreja, contribuindo para o patrimônio religioso da capitania do Ceará.

Diz Manoel da Cunha Per.a Cap.m Comand.e da Ribeira de Jaguaribe, Capitania do Ceará Grande no Bispado de Pern.co que elle pertende edificar na sua fazenda do Boqueirão Freg.a da Russas [...] hua Ermida a Nossa Snr.a das Dores; a qual se faz necess.a para nella ouvirem Missa o Sup.te e Sua Fam.a e igualm.te os Povos circunvizinhos q' distar da moradia do Sup.te Seis legoas a Ermida mais próxima [...] a Sua Pied.e lhe conceda faculd. de p.a d.a fundação concorrendo a Licença do Ordinário a patrimônio Canônico ${ }^{37}$.

\section{As freguesias}

Além da construção das ermidas e capelas, e sua elevação à condição de igreja matriz, o bispo de Pernambuco cuidou de ordenar a demarcação dos limites das freguesias cearenses, que seriam frequentemente percorridas por padres visitadores angariando fundos para os cofres portugueses.

Em sua grande maioria, as vilas foram fundadas onde já existiam paróquias, o que confirma a precedência da organização religiosa quanto à organização político-administrativa ${ }^{38}$. Durante o século XVIII, o número de freguesias superou o número de vilas criadas no Ceará. A capitania alcançou o século XIX com 17 freguesias e 14 vilas.

Em 17 de fevereiro de 1777, D. Tomás da Encarnação Costa e Lima, bispo de Pernambuco, apresentou ao rei de Portugal D. José I uma relação de todas as igrejas paroquiais que pertenciam ao bispado pernambucano - que se estendia desde a foz do São Francisco até Fortaleza, no Ceará, fazendo limite com o do Pará, a oeste, e com o arcebispado da Bahia, ao sul -, abrangendo várias capitanias. Segundo D. Tomás da Encarnação, todas as capelas do bispado ou eram de

engenhos necessárias para a celebração do Santo Sacrifício da Missa e administração dos Sacramentos aos trabalhadores dos mesmos, ou são edificadas pelos povos circunvizinhos com patrimônio competente, nas distancias grandes das suas Matrizes para o referido fim 
dos Sacramentos e Santo Sacrifício, conservando-se nelas hum Sacerdote com licença do próprio Parocho, sem alguns encargos de encapellados ${ }^{39}$.

De acordo com o documento, no território cearense havia uma vigaria colada, 19 amovíveis e 34 capelas (Tabela 2).

\section{Tabela 2}

Freguesias da capitania do Ceará. Ano [1777]

\begin{tabular}{|c|c|c|c|c|c|}
\hline TIPOS DE FREGUESIA & 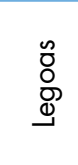 & $\frac{\mathscr{0}}{0}$ & $\begin{array}{l}\tilde{0} \\
\frac{0}{0} \\
0 \\
0 \\
0 \\
0 \\
\tilde{O}\end{array}$ & $\begin{array}{l}\text { Oั } \\
\text { 오 }\end{array}$ & 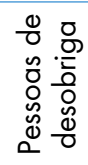 \\
\hline \multicolumn{6}{|l|}{ VIGARIA COLADA } \\
\hline Freguesia de São José do Aquiraz & 26 & 6 & 1 & 530 & 2251 \\
\hline \multicolumn{6}{|l|}{ CURATOS AMOVÍVEIS } \\
\hline Freguesia de São Gonçalo da Serra dos Cocos & 200 & 2 & 0 & 545 & 875 \\
\hline Freguesia de São José da Macabocoeira & 56 & 0 & 1 & 225 & 1358 \\
\hline Freguesia de Nossa Senhora da Assunção da Vila da Fortaleza & 40 & 2 & 1 & 467 & 1339 \\
\hline Freguesia de Nossa Senhora do Rosário das Russas & 30 & 5 & 2 & 1027 & 4525 \\
\hline Freguesia de Santo Antonio de Quixeramobim & 80 & 1 & 1 & 226 & 924 \\
\hline Freguesia de Nossa Senhora da Expectação da Vila do Icó & 90 & 5 & 2 & 725 & 3312 \\
\hline Freguesia de São José dos Cariris Novos & 60 & 2 & 0 & 980 & 3199 \\
\hline Freguesia de Nossa Senhora da Conceição de Amontada & 70 & 2 & 0 & 339 & 1234 \\
\hline Freguesia de Nossa Senhora do Carmo dos Inhamuns & 100 & 4 & 1 & 613 & 2519 \\
\hline Freguesia de Nossa Senhora da Conceição da Vila do Sobral & 60 & 4 & 1 & 678 & 2708 \\
\hline \multicolumn{6}{|l|}{ FREGUESIAS DE ÍNDIOS } \\
\hline Freguesia de Nossa Senhora dos Prazeres da Vila de Soure & 1 & 0 & 0 & 243 & 621 \\
\hline Freguesia de Nossa Senhora da Conceição de Mecejana & 3 & 0 & 0 & 450 & 1060 \\
\hline Freguesia de Nossa Senhora dos Aflitos da Vila de Arronches & 1 & 0 & 0 & 585 & 1472 \\
\hline Freguesia de Nossa Senhora da Penha da Vila do Crato & 3 & 0 & 1 & 324 & 4820 \\
\hline Freguesia de Nossa Senhora da Conceição de Monte Mor Velho & 9 & 0 & 0 & 48 & 165 \\
\hline Freguesia de Nossa Senhora da Palma da Vila de Monte Mor Novo & 40 & 0 & 0 & 99 & 565 \\
\hline Freguesia de Nossa Senhora da Paz da Vila de Arneirós & 1 & 0 & 0 & 103 & 470 \\
\hline Freguesia de Nossa Senhora da Conceição de Almofala & 1 & 0 & 1 & 59 & 137 \\
\hline Freguesia de Nossa Senhora da Assumpção da Vila Viçosa Real & 60 & 1 & 0 & 1538 & 2800 \\
\hline
\end{tabular}

Fonte: CARTA do Bispo de Pernambuco D. Tomás [da Encarnação Costa e Lima] ao rei [D. José I].... e dois documentos anexos. Arquivo Histórico Ultramarino.

39. Ver AHU_ACL_CU_015. Cx. 126. D. 9545, Arquivo Histórico Ultramarino, Lisboa. Reprodução do Projeto Resgate. 
40. Para Antonio Carlos R. Moraes, é exatamente no "apetite territorial de certas sociedades européias" onde se deve buscar o "móvel primeiro da expansão marítima efetuada no 'longo' século XVI". A avaliação do êxito ou do fracasso da conquista está diretamente relacionada à "capacidade plástica" da Coroa de se "apropriar de lugares os mais diversos e moldá-los segundo seus interesses"; cf. Antonio Carlos R. Moraes (2000, p.264).

41. Cf. Jaime Cortesão (1984 p. 606). A noção de território argumentada por Gusmão, durante o impasse das regiões de fronteiras entre a Coroa Portuguesa e a Espanhola, não se pautava na distância alcançada pelo "tiro de canhão", tal como os espanhóis queriam reconhecer a soberania portuguesa; ou seja, como se o território conquistado correspondesse à área adstrita à defesa de suas fortalezas. Por outro lado, ele alegava que a permanência lusitana nas regiões disputadas nas fronteiras, como a Colônia de Sacramento, dependia de suas conexões com outros lugares do Brasil. Ainda segundo Cortesão, o território, para Gusmão, deveria abranger "terras e campanhas vastíssimas" que alargassem "o Brasil até ao Rio da Prata”.cf. idem, p.608. A sua noção explicita a importância de uma continuidade territorial ligando o litoral, os sertões e as regiões de fronteiras; estendendo, assim, o domínio monárquico o mais longe possível. Ver também Renata K. Malcher de Araújo (2000, p. 47). Na América Portuguesa, a estratégia encontrada para fixação foi a fundação de vilas. Com o território pontuado com vilas, garantia-se, e confirmava-se, o estabelecimento da autoridade e da soberania lusitana nas áreas ocupadas. Elas foram, por excelência, a síntese da conquista ; $c$ f. Walter Rossa (2002, p. 289). No espaço estruturado pela rede urbana, as vilas assumem o

\section{A ocupação do território e o Estado português.}

Mesmo diante de um contexło social e físico não propício à fixação, os funcionários do Reino seguiram os caminhos dos boiadeiros e dos representantes da lgreja, e instalaram-se no território. As razões dessa instalação não foram oriundas de causas aleatórias nem foram aleatórios os lugares escolhidos para fundação das vilas: sua finalidade era estabelecer a autoridade civil lusitana.

Primeiro, a criação das vilas não fugiu à lógica do "apetite territorial", que encontrou sua origem ainda na ampliação das rotas marítimas - tanto no Índico como no Atlântico ${ }^{40}$ - e alcançou, no século XVIII, a urgência da continuidade territorial, advogada por Alexandre de Gusmão $0^{41}$. A justificativa era o estabelecimento da ordem, da justiça e aumento do erário real.

Em segundo lugar, as vilas criadas localizavam-se onde outrora os primeiros desbravadores haviam construído suas fazendas e erguido as primeiras ermidas ou capelas da capitania. Eram pontos eminentemente estratégicos, que possibilitavam a fluidez de mercadorias e pessoas - leia-se das boiadas e boiadeiros - e garantiam a conectividade com restante do Brasil e com a dinâmica mercantilista internacional.

Como em todo o restante do território brasileiro, na lógica de apropriação do Espaço cearense pelos portugueses prevaleceu a relação de dominação por meio do nexo sociedade e espaço físico ${ }^{42}$. Nessa perspectiva, a instalação e a consolidação $\circ^{43}$ do poderio luso, além de promoverem a implantação da autoridade do Estado português no Ceará, trouxeram a dimensão da organização espacial do território e das vilas criadas para o centro de toda a vida econômica e social ${ }^{44}$ da capitania.

Entre 1700 e 1822 foram criadas dezoito vilas e seus termos no território cearense: Vila de Aquiraz (1713); Vila de Fortaleza (1723); Vila do Icó (1736); Vila de Santa Cruz do Aracati (1748); Vila Real de Soure, atual Caucaia (1755); Vila de Messejana (1756); Vila Real de Arronches, atual Parangaba (1759); Vila Viçosa Real (1759); Vila de Monte-mor o Novo d'América, atual Baturité (1764); Vila Real do Crato (1764); Vila Real de Sobral (1773); Vila Real de Granja (1776); Vila de Campo Maior de Santo Antônio de Quixeramobim (1789); Vila Nova d'El Rei, atual lpu (1791); Vila de São Bernardo de Russas (1801); Vila de São João do Príncipe, atual Tauá (1802); Vila de Jardim (1814); e a Vila de Lavras da Mangabeira (1817).

A fundação das vilas, além de prosseguir com o movimento de centralização administrativa do Estado português (ante a dispersão reinante nos primeiros 40 anos de colonização do Cearál e garantir a continuidade do território, promoveu um ordenamento espacial da capitania a partir de uma razão distante, pela delimitação das áreas dos novos núcleos e de seus termos.

No que se refere ao espaço urbano, a Coroa portuguesa orientou a implantação das vilas segundo os padrões da escola do urbanismo português setecentista. Mas as orientações urbanísticas tiveram de adaptar-se às condições sociais e físicas de cada vila fundada, fazendo com que nem todas as diretrizes 
fossem de fato adotadas. No âmbito regional, no ato de criação de cada vila, as dimensões dos termos mudavam de tamanho quando o território era novamente repartido. Sem deixar claros os critérios adotados, alguns mantinham grandes dimensões e outros, dimensões reduzidas. Em algumas situações, o reordenamento do território foi razão de entraves políticos entre diversos agentes que defendiam os interesses econômicos das vilas envolvidas. Em ambas as situações, entretanto, o que se observou foi o ordenamento do espaço, tanto em escala regional como na de vila.

Até os primeiros anos do século XIX, com exceção de Aquiraz e Fortaleza, localizadas no litoral, as demais vilas de brancos fundadas situavam-se em pontos estratégicos para produção, reprodução e circulação da atividade da pecuária. Assentavam-se nos cruzamentos das estradas das boiadas e na foz dos principais rios da capitania: os rios Jaguaribe, Acaraú e Coreaú. Pelo lugar geográfico das vilas, confirma-se o interesse português pela atividade produtiva.

Aracati localizava-se na foz do rio Jaguaribe, para onde seguia a Estrada Geral do Jaguaribe. Quixeramobim estabeleceu-se no cruzamento das estradas que vinham de Granja, Sobral, Crateús, de Santa Quitéria, e da Paraíba. Sobral ligava o sertão central com o litoral noroeste da capitania. De Tauá, podiase seguir para Oeiras, no Piauí, passando por Crateús, ou então para lcó. Russas estava na Estrada Geral do Jaguaribe, e lcó, situada no cruzamento desta com a Estrada Nova das Boiadas, comunicava-se diretamente com o Piauí, com a Paraíba e com Aracati, no litoral cearense ${ }^{45}$.

As vilas de índios de Messejana, Soure (atual Caucaia) e Arronches (atual Parangaba) foram implantadas próximas da Fortaleza de Nossa Senhora da Assunção, onde já existiam pequenas missões estabelecidas pelos inacianos. Já as vilas do Crato e de Monte-mor o Novo d'América (atual Baturité) estavam situadas no sopé das serras do Araripe e de Baturité. A missão da lbiapaba, futura Vila Viçosa Real (atual Viçosa), fora implantada na serra da lbiapaba. Levantamos a hipótese de que as suas localizações geográficas, nos arredores das serras do Araripe e de Baturité ou no alto da lbiapaba, estavam diretamente relacionadas à possibilidade de capitalização da mão de obra indígena com a agricultura.

\section{As diretrizes urbanísticas para a capitania do Ceará.}

A Carta Régia do lcó46, de 20 de junho de 1736, determinava que, após a escolha do sítio junto à matriz existente, em um lugar saudável e com um bom provimento de água, dever-se-ia marcar a praça e dali delinear ruas retas, bastante largas, deixando espaço " $p^{a}$ se edificarem as cazas nas mesmas directuras e igualdade com seus quintaes competentes de sorte que a todo o tempo se conservem a mesma largura das ruas". Após a marcação das ruas, se demarcaria o lugar em "o qual se hajam de formar a casa de Camara e das Audiências e a cadea para que nas mais áreas se possam edificar as casas dos moradores com seus quintaes na forma que parecer a cada um como fiquem a facia das ruas" 47 . Deixar-se-ia, ainda, área bastante para o logradouro. lugar de elo de comunicação entre as estradas coloniais e de transmissão do discurso metropolitano. Aqui, a urbanização foi parte integrante do processo de colonização; ver Nestor Goulart Reis Filho (1968).

42. Sonia Barrios (1986, p.68) considera as praticas políticas "como as ações sociais que têm por finalidade a conquista ou a detenção do poder". Elas sempre envolvem o "estabelecimento de uma relação de dominação, caracterizando o nexo homem/ homem, que se expressa numa relação de apropriação, característica do nexo sociedade/espaço físico"

43.Aqui tomamos as "etapas dos processos de colonização" propostas por Moraes para entender como a Coroa se instala na capitania cearense. $O$ autor afirma que a sequência " - descoberta-exploração, conquista-instalação, consolidação-expansão, complexização - manifesta-se de forma recorrente nas áreas onde se instala o processo colonizador", sendo observável em "diferentes épocas conforme os espaços enfocados do continente americano". No caso da "instalação", "tratava-se de uma etapa inicial de submissão das populações locais e de apropriação dos lugares envolvendo a pioneira edificação dos assentamentos europeus na América". Na etapa de "consolidação" percebe-se a "plena montagem das estruturas produtivas, implicando já a instalação de equipamentos e razoável dispêndio de trabalho morto na colônia". Ela "geralmente [fez-se] acompanhar de alterações na estrutura fundiária, no estatuto jurídico das propriedades, e ainda na organização do mercado de terras e de trabalho"; cf. Antonio Carlos Robert Moraes (2000, p. 276-279).

44. Também a lógica da valorização espacial nas formações latino-americanas é 
minuciosamente posta por Moraes (2000, p. 282). O autor afirma que "havendo conquista, a dimensão espacial vem ao centro da estruturação da vida econômica e social, tornando-se uma determinação histórica”. Após o povoamento, a fixação no território significou a "instalação de equipamentos, a fixação de valor". Tudo respondendo à lógica da conquista, "até o momento em que o volume do capital internalizado começa a gerar interesses locais, que se podem antagonizar ou não com os da metrópole, ao sabor das conjunturas".

45. Cf. Clovis Ramiro Jucá Neto (2007, p. 244).

46. Cf. AHU_ACL_CU_017. Cx.9.D. 564.Arquivo Histórico Ultramarino, Lisboa. Projeto Resgate, onde se encontra transcrita a Carta Régia do Icó também está transcrita em Gustavo Barroso (1962); e em Paulo F. Santos (1968, p. 42-43).

47. Ibidem.

48. Cf. Paulo F. Santos (1968, p. 44-45).

49. Ibidem.

50. "Termo de demarcação e assignação do terreno" - "Registro dos Autos da erecção da real vila de Monte-mór o Novo da América, na capitania do Ceará". Publicado na Revista do Instituto do Ceará. Fortaleza.Tomo 05. 1891

51. Uma (1) braça correponde a cerca de $2,2 \mathrm{~m}$ de comprimento

52. Um (1) palmo correponde a cerca de $22,6 \mathrm{~cm}$.

53.A Carta Régia da Vila Real do Crato encontra-se parcialmente transcrita pelo Dr. Francisco Freire Alemão, botânico e chefe da comissão científica que correu a província do Ceará na segunda metade do século XIX. Ver Anais da Biblioteca Nacio-
A Carta Régia de 10 de fevereiro de 174848, após declarar o "lugar do Aracati porto dos barcos do rio Jaguaribe" como o mais acertado para a "Vila de Santa Cruz do Aracati", determinou as "demarcações tanto da praça ruas lugares para edifícios públicos rossios e logradouros". Naquele mesmo dia, o ouvidor Manuel José de Farias escolheu o sítio "chamado Cruz das Almas" 49 para ser o lugar da praça.

Na segunda metade do século XVIII, a ação pombalina no Ceará fundou seis vilas a partir de antigos aldeamentos indígenas.

Os autos de elevação da antiga missão de Nossa Senhora da Palma à condição de "Vila de Montemor o Novo d'América"50 (Baturité) estabeleceram uma área de 165 braças $^{51}$ de comprimento por 135 braças de largura para sua instalação, onde seria alinhada uma praça de 80 braças de comprimento por 45 de largura. Também determinou que cada lado da praça deveria ter 48 casas, das quais 44 com 30 palmos ${ }^{52}$ de frente, e as outras 4 destinadas para as "casas de camaras e mais oficinas publicas", com 60 palmos; que a igreja tinha 80 por 40 palmos. Além disso, ordenou o tamanho dos lotes da igreja, da Casa de Câmara e Cadeia e demais oficinas, e ainda a largura das ruas.

Um pouco mais de um mês após a fundação de Monte-mor o Novo d'América, no dia 14 de junho de 1764, o mesmo ouvidor-geral Victorino Soares Barbosa, criou a Vila Real do Crato ${ }^{53}$. O termo de demarcação determinou para a vila uma área de 300 braças quadradas, com uma praça central com 30 braças de cada lado, com uma igreja de 50 palmos de frente por 100 de fundo em seu lado oeste, além de 20 palmos na frente para futuras ampliações. Também estabeleceu 11 ruas com 40 palmos, onde deveriam ser demarcadas 222 áreas para moradias, sendo 70 na praça central.

Nas cartas régias de instalação das demais vilas de índios - a Vila Nova de Soure (Caucaia), Vila Viçosa Real, Vila Nova de Arronches (Parangaba) e Vila de Messejana ${ }^{54}$, as diretrizes ordenadoras do espaço se limitaram à determinação do lugar da praça no largo da Igreja Matriz, defronte ao terreiro que devia ser "medido e balizado" para a construção dos edifícios públicos.

Também nas cartas régias que orientaram a implantação das outras vilas de brancos, na segunda metade do século XVIII, quase não foram explicitadas preocupações urbanísticas ${ }^{55}$. Quando apareciam, achavam-se dispersas nos textos dos autos, alertando unicamente para o alinhamento das casas, como no "Termo de consignação do território", da Vila de Quixeramobim"56, assinado em 15 de julho de 1789 pelo ouvidor-geral Manoel Magalhães Pinto e Avellar de Barbedo, pelo escrivão Manoel Martins Braga e os demais oficiais da Câmara.

\section{A delimitação dos termos}

Outra preocupação durante os procedimentos de criação das vilas foi o estabelecimento de seus termos, ou seja, a área de sua jurisdição. Embora não tenha sido possível estabelecermos os critérios exatos para demarcação de seus limites, geralmente eles coincidiam, na segunda metade do século XVIII, com as 
áreas das freguesias já existentes ou de seus distritos, às quais eram acrescentados outros terrenos.

Ainda em relação à delimitação dos termos, por todo o século persistiu a problemática de suas grandes extensões e, consequentemente, das grandes distâncias que eram percorridas para a implantação da justiça. Foi assim que, ainda na primeira metade do século XVIII, a Carta Régia de lcó alertou para as 80 léguas que separavam esta vila da sede da comarca em Aquiraz, prejudicando "a boa administração da justiça" e inevitavelmente, retardando a necessária "aquietação daqueles povos"; ou seja, tanto da população indígena que resistia ao avanço da pecuária como dos envolvidos na célebre briga por posse de terra entre as famílias Montes e Feitosa. No início do século XIX, a grande distância entre a vila do lcó e de seu distrito, a povoação de Tauá, esteve em pauta nas considerações que elevaram o povoado à condição de Vila de São João do Príncipe ${ }^{57}$. No alvorecer do século XIX, a capitania achava-se dividida em 14 termos correspondente a cada vila criada.

\section{O desenho das vilas cearenses no início do século XIX}

A reconstituição gráfica da organização espacial proposta pelos portugueses por meio dos dados fornecidos no Termo de Demarcação, demonstra que, entre as vilas fundadas no Ceará, a única executada de modo fiel à legislação foi a vila de índio Monte-mor o Novo d'América ${ }^{58}$, verdadeira expressão pombalina na capitania cearense. Nem mesmo nas duas principais vilas do Ceará setecentista - a vila do Icó e a vila do Aracati, que ocupam posições estratégicas para as atividades em torno da pecuária - os desígnios urbanísticos portugueses foram implantados com tanta fidelidade.

A despeito das diretrizes urbanísticas da Carta Régia da Vila de Santa Cruz do Aracati, que propunham a instalação da praça fundacional um quilômetro ao norte do antigo povoado do porto das Barcas, e dos problemas relacionados à salubridade pública resultantes da presença das salgadeiras das carnes cearenses, o Aracati desenvolveu-se no entorno da antiga povoação, onde já moravam os envolvidos com a atividade econômica da pecuária; ou seja, o abate, a salga e comercialização do charque.

No início do século XIX, a vila não passava de uma longa rua entrecortada por becos e travessas. Ela foi descrita pelos viajantes Henry Koster ${ }^{59}$ e George Gardnerb0, e desenhada, em 1813, por Antonio José da Silva Paulet, engenheiro-mor do Reino, e, em 1825, por João Bloem, capitão do Imperial Corpo de Engenheiros. Tanto na descrição como nos desenhos, o Aracati não passava de comprida rua, sem presença de praça central. Também não se encontravam, na área determinada para a praça, a Casa de Câmara e Cadeia tampouco a lgreja Matrizol.

Na Planta do porto e da Vila do Aracati (Figura 2) elaborada por Silva Paulet em 1813, e na Planta da Barra e rio de Jaguaribe, do engenheiro João Bloem, de 1825, que contém em detalhe o desenho do Aracati (Figura 3), a vila nal. Manuscritos do botânico Freire Alemão. Localização: I-28, 9, 10.

54.As cartas régias de fundação da Vila Nova de Soure, da Vila Viçosa Real, da Vila Nova de Arronches e da Vila de Messejana foram publicadas por Guilherme Ch. Studart (1892, p. 226-280).

55. Não encontramos qualquer referência às diretrizes urbanísticas nas documentações em relação à vila de Sobral durante o século XVIII, publicadas pelo padre Francisco Sadoc deAraújo (1974); nem em D. José Tupinambá da Frota (1995).

56. O Termo de consignação do território da vila de Quixeramobim está transcrito em João Baptista Perdigão de Oliveira (1890).

57.A Carta Régia justificando a criação da Vila de São João do Príncipe (Tauá) está transcrita em Aroldo Cavalcanti Mota (2001, p. 114-115).

58. Cf. José Liberal de Castro (1999, p.50).

59. Cf. Henry Koster (2003, p.167-168).

60. Cf. George Gardner (1975, p. 81).

61. Ver Clóvis Ramiro Jucá Neto (2007). 


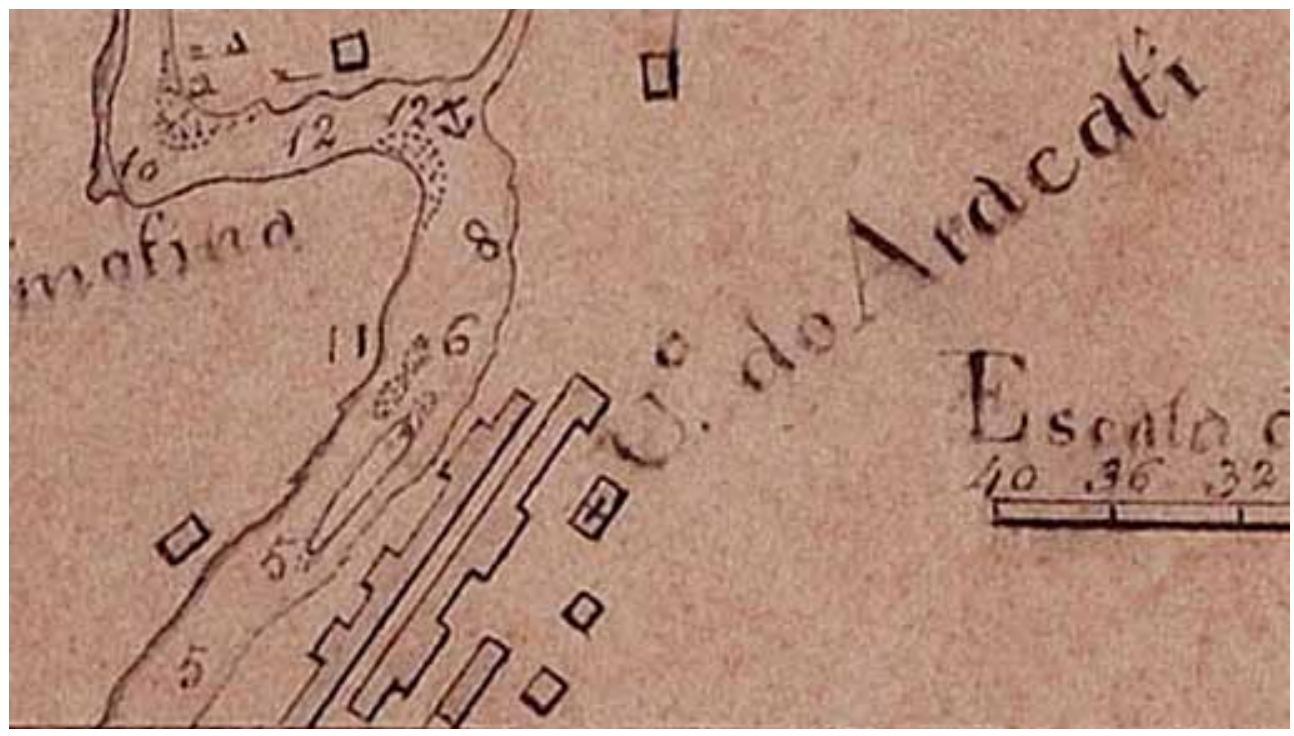

Figura 2 - Antonio José da Silva Paulet. Planta do Aracati, 1813. Detalhe de Carta da capitania do Ceará... Acervo da Mapoteca do Itamarati / Ministério das Relações Exteriores, Rio de Janeiro.

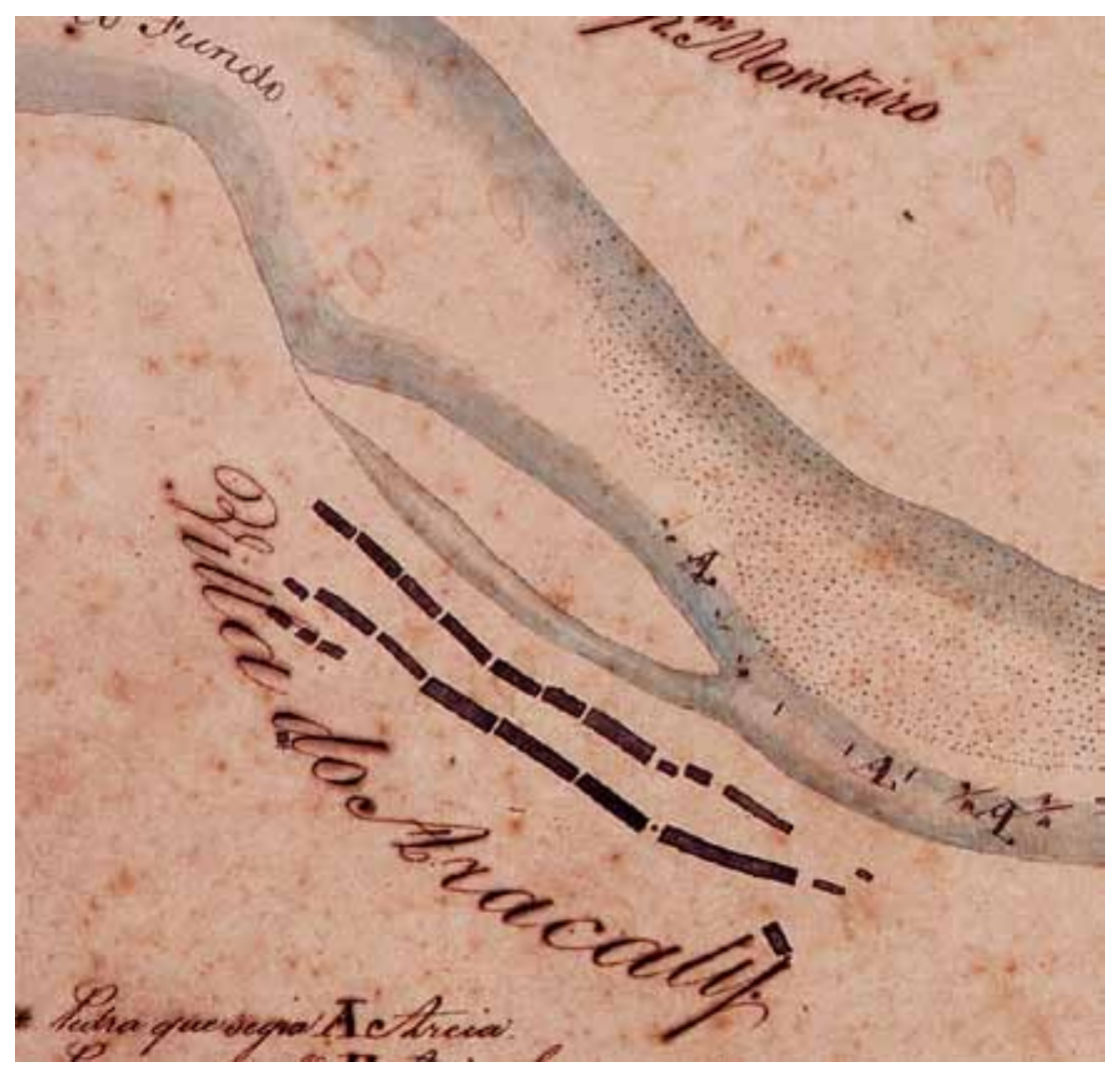

Figura 3 - João Bloem. Planta do Aracati, 1825. Detalhe de Planta da Barra e rio de Jaguaribe... Acervo do Arquivo Histórico do Exército, Rio de Janeiro. 
não passa de uma longa rua - que congregava as do Pelourinho, das Flores e de Santo Antônio - paralela ao rio Jaguaribe. Margear o rio foi, ainda na primeira metade do século XVIII, uma das primeiras prerrogativas das ordenações régias. As demais ruas presentes nos livros de aforamentos do século XVIII não são demarcadas; excetuando-se um pequeno trecho da rua Direita, em um espaço compreendido entre a lgreja dos Prazeres e a do Rosário dos Pretos, na rua do Piolho.

$\bigcirc$ desenho de Paulet apresenta uma vila bastante alinhada, reta e sem interrupções, não chegando às minúcias dos becos e travessas que cortavam a rua principal em toda a sua extensão, tampouco expressando os vazios das quadras e a falta de alinhamento de certos trechos. Já o risco de Bloem se aproxima mais da realidade. $\bigcirc$ alinhamento não é tão rigoroso, sendo demarcados os espaços vazios entre as quadras, ou no meio delas, e as várias transversais que cortavam a rua principal. Do lado nascente, podem-se contar cinco travessas e, já quase no extremo norte da vila, uma área livre com um ponto central dentro do alinhamento das quadras, que acreditamos ser a nova praça do Pelourinho, onde, defronte, estava a Casa de Câmara e Cadeia, após sua retirada dali onde outrora fora pensado o lugar da praça. No poente, identificamse sete pequenas ruas transversais e, também, mais para o norte, mas ainda no alinhamento da rua principal e antes da última quadra, uma área livre, sem uma clara definição se era uma praça ou não, mas certamente ainda desocupada. $\bigcirc$ desenho de Paulet traz somente a lgreja Matriz de Nossa Senhora do Rosário; e o de Bloem, além dessa, outra que acreditamos ser a do Rosário dos Pretos. Em ambos não são representadas a lgreja do Bomfim, a lgreja dos Prazeres e a capela para Nosso Senhor dos Navegantes, aforada no início do século XIX, na travessa que ligava a rua de Santo Antônio e a Matriz.

Comparando-se o que, nos desenhos de Paulet e Bloem, se apresenta como construído não só com a área da vila - apreendida pela localização das ruas listadas nos termos de cordeação (alinhamento) do Livro de Aforamentos de 1775 - mas também com os limites estabelecidos pela medida de n. 10 do provimento de 1780 - que determinava uma poligonal de crescimento do núcleo em decorrência da extrema dispersão que a sua materialidade construída apresentava cerca de trinta anos após a sua fundação -, conclui-se que ela, com exceção de sua rua principal, continuava inteiramente dispersa no início do século XIX, sem uma definição clara de seu arruamento, a ponto de não serem as demais ruas levadas em consideração nos desenhos dos engenheiros.

Também no desenho de ambos não há sinal da praça, demonstrando que ela não foi formalmente estruturada, e que a condição, periférica e residual, da área idealizada para sua locação no extremo sul da vila manteve-se no decorrer dos anos. A praça nunca deixou de ser um grande areal - como se denomina no Ceará um grande descampado, na maioria das vezes desprovido de sombra, - na extremidade oposta ao ancoradouro. Durante a segunda metade do século XVIII, o seu caráter simbólico de centro cívico, marco número um de demarcação da vila ou de onde todo o restante se origina e por analogia "centro do mundo, do berço da vida e da civilização"62, que a presença do pelourinho 
63. Cf. George Gardner (1975, p.87).

64. Cf. Clóvis Ramiro Jucá Neto (2007, p. 396). só reforçava esvai-se completamente. E esvai-se por não ocupar uma posição central na vila, por continuar no extremo sul do Aracati, pela transferência do pelourinho para outra praça no norte da vila, onde estava a Casa de Câmara e Cadeia, e pelo sentido aglutinador do espaço setentrional do núcleo, onde se davam a produção da carne salgada, as transações comerciais, e onde se concentraram os setores mais abastados, a maioria dos seus sobrados, e os edifícios institucionais representativos do poder público e religioso; e tudo isto nas proximidades do porto.

Em agosto de 1836, o inglês Gardner deixou o Aracati em direção ao lcó. Segundo o viajante, o núcleo consistia de "três ruas principais", que corriam no sentido norte-sul, cortadas por outras menores. A principal rua era larga e tinha "algumas lojas bem sortidas" 63 . $\bigcirc$ espaço do lcó foi descrito sem qualquer referência à praça idealizada há cem anos pelos portugueses ${ }^{64}$.

Primórdios da organização do espaço territorial

e das vilas cearenses: a falta de investimento

Para a organização espacial do território das vilas criadas, foram fundamentais as relações estabelecidas entre elas. Contudo, como a produtividade e a rentabilidade da pecuária continuaram pequenas por todo o século, não houve razão nem justificativa econômica suficientemente forte para um investimento técnico e de capital, por parte dos portugueses, para adequar plenamente as especificidades locais às suas necessidades lusitanas, ou vice-versa. Também logo se desfez o sonho do eldorado de minas de prata e de ouro no sertão.

Além da inexistência de razões econômicas, também não houve motivos geopolíticos que justificassem maiores investimentos tecnológicos na capitania, fossem relativos à sua defesa ou às instalações de suas vilas. Primeiro, porque a soberania portuguesa na região, desde a expulsão dos holandeses em 1654, já não era ameaçada por estrangeiros; depois, porque, já no Tratado das Tordesilhas, a zona sertaneja do Nordeste do Brasil - e, em nosso caso, o atual território do estado do Ceará já pertencia a Portugal. Além disso, a caminho da região amazônica, era bem mais fácil alcançar-se o Maranhão e o Pará por mar, vindo diretamente de Lisboa, do que cruzando o sertão.

Não é difícil afirmar que o Ceará, ocupando uma posição periférica no conjunto dos interesses econômicos e geopolíticos portugueses, ficou à margem das ações que envolveram investimentos tecnológicos com vistas à adequação das capitanias e de suas vilas às ações lusitanas ordenadoras do espaço. Não é à toa que, até o final do século XVIII, têm-se notícias de somente quatro engenheiros na capitania cearense, e que eles quase nada propuseram. 
Os engenheiros militares portugueses e a capitania do Ceará

Por todo o Setecentos, os documentos cearenses revelam o incômodo causado pela ausência de técnicos - engenheiros, mestres de obras e carpinteiros, dentre outros - e de instrumentos que viabilizassem a delimitação dos termos das vilas, a implantação dos núcleos, a construção das casas de câmara e cadeia, ou que atribuíssem ao forte da vila de Fortaleza outra imagem que não fosse a de ruína.

Neste sentido, o interesse metropolitano pela apreensão territorial da capitania é equivalente ao reduzido número de engenheiros que aí estiveram entre 1700 e 1800 e às elaborações tardias de sua cartografia, que só ocorreram no último ano do século XVIII e nos primeiros do século XIX. Também, como já sabemos, embora as cartas régias divulgassem as diretrizes urbanísticas metropolitanas para as vilas fundadas na capitania, pouco ou quase nada das normas promovidas foram de fato implantadas.

No século XVI, o número de engenheiros na Índia e na África variava entre cinco e dez, sendo pelo menos o dobro do número existente no Brasil. No início do século XVII, seu número na América Portuguesa, em comparação com os da Índia, já era superior; e, no começo do século XVIII, a quantidade desses técnicos oscilava entre 40\% e 50\% do total da Metrópole 65 . Deste universo setecentista, quatro engenheiros estiveram no Ceará: Diogo da Silveira Veloso, Luis Xavier Bernardes, Jerônimo Mendes de $\mathrm{Paz}^{66}$ e Custódio Francisco de Azevedo. Os três primeiros estavam envolvidos com a procura de minas de ouro e de prata e com as reformas da Fortaleza de Nossa Senhora de Assumpção. Somente Custódio Francisco de Azevedo envolveu-se com a implantação de uma vila - Monte-mor o Novo d'América (Baturité), com a delimitação de termos, e com a construção de sedes administrativas, como as casas de câmara e cadeia. Nem em seu espaço territorial, sequer no de suas vilas, a presença dos engenheiros na capitania chegou a traduzirse em intervenções, confirmando o reduzido investimento em técnica, por parte do governo português, no território cearense.

panorama mudou de figura após 1799, quando a capitania cearense se tornou autônoma da capitania de Pernambuco ${ }^{67}$. De 1799 até 1822 , o território do Ceará foi plenamente cartografado, projetou-se uma fortificação de pedra e cal e um novo desenho para a vila de Fortaleza. Nos primeiros vinte anos do século XIX, estiveram na capitania cearense os engenheiros militares Francisco Xavier Torres ${ }^{68}$, João da Silva Feijó, e Antonio José da Silva Paulet.

\section{território desenhado}

Se comparado com o restante do Brasil, o Ceará foi - durante o século XVIII - tardiamente ocupado. Se persistirmos na comparação, também seu território foi tardiamente cartografado. Essa sua ocupação tardia, assim como a sua tardia representação cartográfica, revela uma posição secundária dos interesses lusitanos em relação a uma melhor apreensão da região.
65. Cf. Nestor Goulart Reis Filho (1968, p.70).

66. No grupo de técnicos que estiveram na capitania do Ceará no século XVIII, incluímos Jerônimo Mendes de Paz como engenheiro (embora sua formação não esteja comprovada), por sua reconhecida habilidade técnica, capaz de cartografar a região das minas dos Cariris.

67. Somente no último quartel do século XVIII, dirigentes locais iniciaram uma campanha frente a Portugal, que visava à separação administrativa da capitania cearense da capitania de Pernambuco. Relatórios e memórias descritivas sobre o Ceará, elaboradas por seus capitães-mores e ouvidores, foram enviados ao Reino, procurando demonstrar ao Conselho U1tramarino as possibilidades concretas do seu desenvolvimento econômico. Em alguns destes balanços foram apontadas novas fontes de arrecadação para o erário real, tais como o cultivo do algodão, do linho, da água ardente; noutros, riquezas minerais foram arroladas.Também amostras comprobatórias foram enviadas para o Reino. Toda a ação esboçava um projeto de desenvolvimento para a Capitania justificando a independência administrativa cearense. A Carta Régia de 17 de Fevereiro de 1799 declarou o Ceará administrativamente autônomo de Pernambuco; cf. Barão de.Studart (2001, p. 426). A autonomia administrativa implicou no delineamento espacial do seu território, e na urgência de sua representação.

68. Logo que chegou à Capitania, Francisco XavierTorres tratou de fazer o levantamento da planta da Fortaleza da Assunção e do reduto de São Luís do Mucuripe; ver Clóvis Ramiro Jucá Neto (2007). 
69. Sobre Feijó, ver Paulino Nogueira (1888). Feijó nasceu em 1760, na cidade de Guaratiba, distrito da cidade do Rio de Janeiro e faleceu em 1824. Pertenceu ao corpo de engenheiros do Reino e exerceu o secretariado do governo das ilhas de Cabo Verde. Foi ainda sócio correspondente da "academia real das sciencias de Lisboa"; cf. Francisco Marques de Souza Viterbo, (1998, v.1, p. 319).

70.A interrogação entre colchetes está no original. Isto é, quem a fez não confiava que fossem mesmo léguas de 20 ao grau, equivalentes a $5555,56 \mathrm{~m}$, sendo a medida
A primeira carta com as demarcações das fronteiras cearenses de que se tem notícia, sem especificação de data, é a carta Capitania do Ceará; dividida pelo campo illuminado de cor (Figura 4), de autoria (bastante provável) do

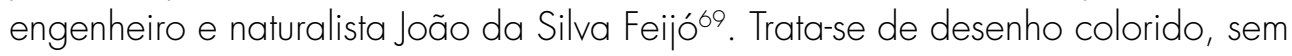
autor nem data explicitados, sobre cartão. No canto esquerdo, apresenta a seguinte nota: "Petipé de 20 léguas de caminho q' são as léguas de 20 ao grao"70. Nobre considera Feijó o "pioneiro dos estudos cearenses" e intelectual típico de uma época - a do "iluminismo e do enciclopedismo europeus"71.

Segundo José Liberal de Castro, "A expressão 'dividida pelo campo iluminado' [do mapa Capitania do Ceará; dividida pelo campo illuminado de cor] significa dizer que o território é aquele que fica iluminado por um traço de contorno colorido ("iluminado") que começa e termina no litoral"72. A capital, as vilas e as povoações são "decodificadas por meio de convenções diferenciadas [e] aparecem sobre o próprio desenho"73. As vilas representadas são "as da

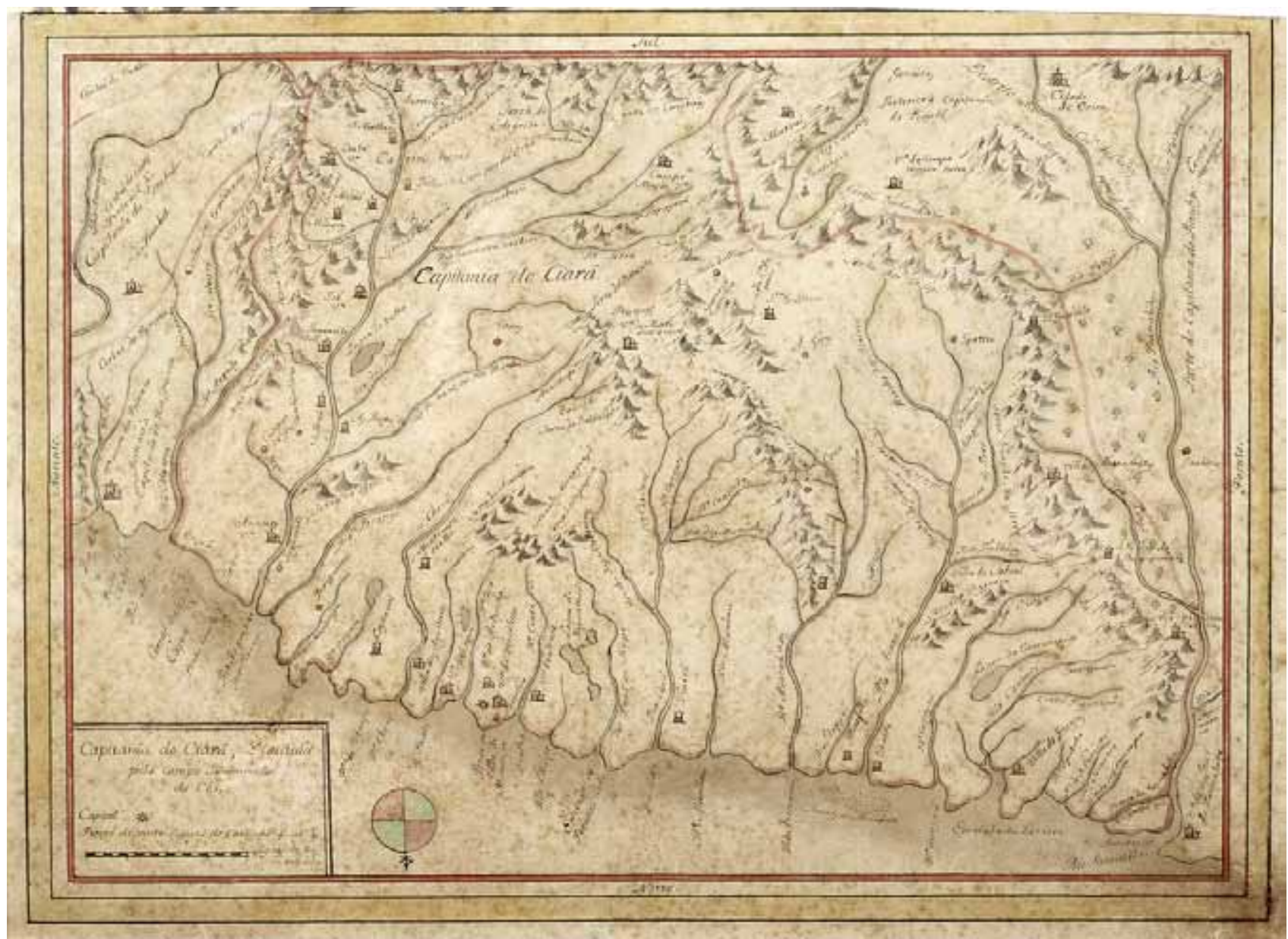

Figura 4 - Capitania do Ceará; dividida pelo Campo Illuminado de cor. Acervo do Arquivo Histórico do Exército. Rio de Janeiro. 
Fortaleza, Arronches [Parangaba], Messejana, Soure [Caucaia], Aquirás, Aracati, Icó, Crato, Campo Maior (Quixeramobim), Sobral, Granja, Vila Nova d'El Rei (Guaraciaba), Viçosa e Montemor o Novo (Baturité)"74. E Liberal de Castro continua, explicando que o território é desenhado de uma forma "achatada" na região sul, fazendo com que a Vila do Crato fique mais próxima da costa do que a povoação do Arneirós. E que a capitania avança no atual território do Piaú, alcançando o rio Parnaíba.

Esta carta foi provavelmente elaborada entre meados de 1799 e o fim de 1800 por Feijó75; ou seja, pouco tempo depois da sua chegada.

A sugestão da data, ainda segundo Liberal de Castro, deve-se à análise dos seguintes dados:

a. a vila de Fortaleza é "citada como a 'capital da capitania', condição esta somente referida oficialmente após a autonomia administrativa do Ceará, obtida no início do 1799".

b. Russas ainda aparece como povoado. Ela é criada como vila somente em 1801

c. Quanto à autoria da carta, Castro afirma ser de Feijó, que chegou ao Ceará "quase conjuntamente" com o governador Bernardo de Vasconcelos. O autor reconhece que "Somente o Naturalista, amparado por sua competência profissional e em face da posição ocupada nos quadros técnicos e burocráticos da Capitania, poderia executar tal tarefa"76.

No ano de 1800, o visitador Mariano Gregório do Amaral77, natural do Rio de Janeiro, percorreu o território e desenhou o Mapa Geographico da Capitania do Seará, estabelecendo os limites das 17 freguesias - com suas matrizes e capelas - existentes na capitania. $\bigcirc$ risco tem como base a carta da Capitania do Ceará; dividida pelo Campo Illuminado de cor, de Feijó, acrescida de informações sobre a rede eclesiástica na capitania no início do século XIX. Além de estabelecer os limites das 17 freguesias existentes, enumera todas as matrizes e capelas.

Em 1810, João da Silva Feijó elaborou a Carta Demonstrativa da Cappitania Do Ceará Para servir de plano a sua carta Topographica Como o próprio nome expõe, trata-se de um rascunho, a nanquim sobre cartão, que vai servir de plano para outra carta. Nele, estão marcadas as vilas da Fortaleza, do Aquiraz, do Aracati, do lcó, da Viçosa Real, de Sobral e a Vila Nova d'El Rei. Mas, embora já fundadas, foram omitidas do desenho as vilas de Arronches (Parangaba), Baturité e Crato. $O$ contorno do território já se assemelha ao atual, conquanto "avance de forma avultada a reentrância correspondente à bacia do Poti"78, hoje a região em torno de Crateús. Os traçados dos rios maiores [da capitania] - o Jaguaribe, o Coreaú e o Acaraú - além do Xoró (sic) [Choró], Pacoti e Ceará, já se aproximam da realidade. $\bigcirc$ mesmo não se observa em relação ao rio Poti, assinalado como o rio das Piranhas ${ }^{79}$. oficial da légua marítima; ver nota 21 , neste.

71. Ver Geraldo da Silva Nobre (1997)

72. Cf. José Liberal de Castro (1997, p. 25).

73. Idem, ibidem.

74. Idem, ibidem.

75. Idem, p. 26.

76. Idem, ibidem.

77. Mariano Gregório do Amaral era natural do Rio de Janeiro. Até o momento sabemos poucas informações sobre o religioso. Segundo um requerimento anterior à data de 28 de Julho de 1804 o próprio Mariano Gregório do Amaral escreveu ao príncipe regente D. João pedindo que ordenasse a José Maria de Araujo, bispo eleito de Pernambuco, que este examinasse seus requisitos e o aceitasse para a Cadeira de Desenho no Seminário Episcopal, pois afirmava possuir as qualidades necessárias, por ser aluno da Real Academia de Desenho de Lisboa. Em resposta ao requerimento, no dia 28 de julho de 1804, o Bispo de Pernambuco, afirma que Gregório do Amaral não "mostrou pello menos com certidoens legais aos Professores, com que deveria documentar o seu requerimento", fazendo-o preferir o sacerdote João Ribeiro Pessoa,"actualmente empregado"; cf. AHU_ACL_ CU_015, Cx. 249, D.16728. Arquivo Histórico Ultramarino, Lisboa. Reprodução do Projeto Resgate.

78. Cf. José Liberal de Castro (1997, p. 27)

79. Idem, ibidem. 
80. Liberal de Castro afirma não haver dúvida em atribuir a autoria do trabalho a Feijó "arrimado no fato de ele próprio declarar haver 'organizado e delineado' a Carta Demonstrativa da Capitania, já apresentada antecipadamente, 'para servir de plano a sua carta Topográphica'”; cf. José Liberal de Castro (1997,p. 28).

81. Idem, p. 28.
A carta para a qual o rascunho serviu de base foi a Carta Topographica da Capitania do Ceará que a SAR o Príncipe Regente Nosso Senhor Dedica Luiz Barba Alardo de Menezes, no ano de 1812, também de Feijóo (Figura 5).

A importância dessa carta deve-se tanto a suas informações gráficas como à memória descritiva, dividida em cinco tópicos, que contornam o desenho central:

a. "Taboa ltinerária", um quadro de "distâncias em 'legoas portuguesas', entre 16 vilas da Capitania, recorrendo a um sistema de abcissas e ordenadas" 81 . São estabelecidas as distâncias entre as vilas de Aquiraz, Aracati, Arronches, São Bernardo, Campo Maior, Crato, Fortaleza, Granja, Icó, São João do Príncipe, Messejana, Vila Nova d'El Rei, Sobral, Soure e Vila Viçosa Real.

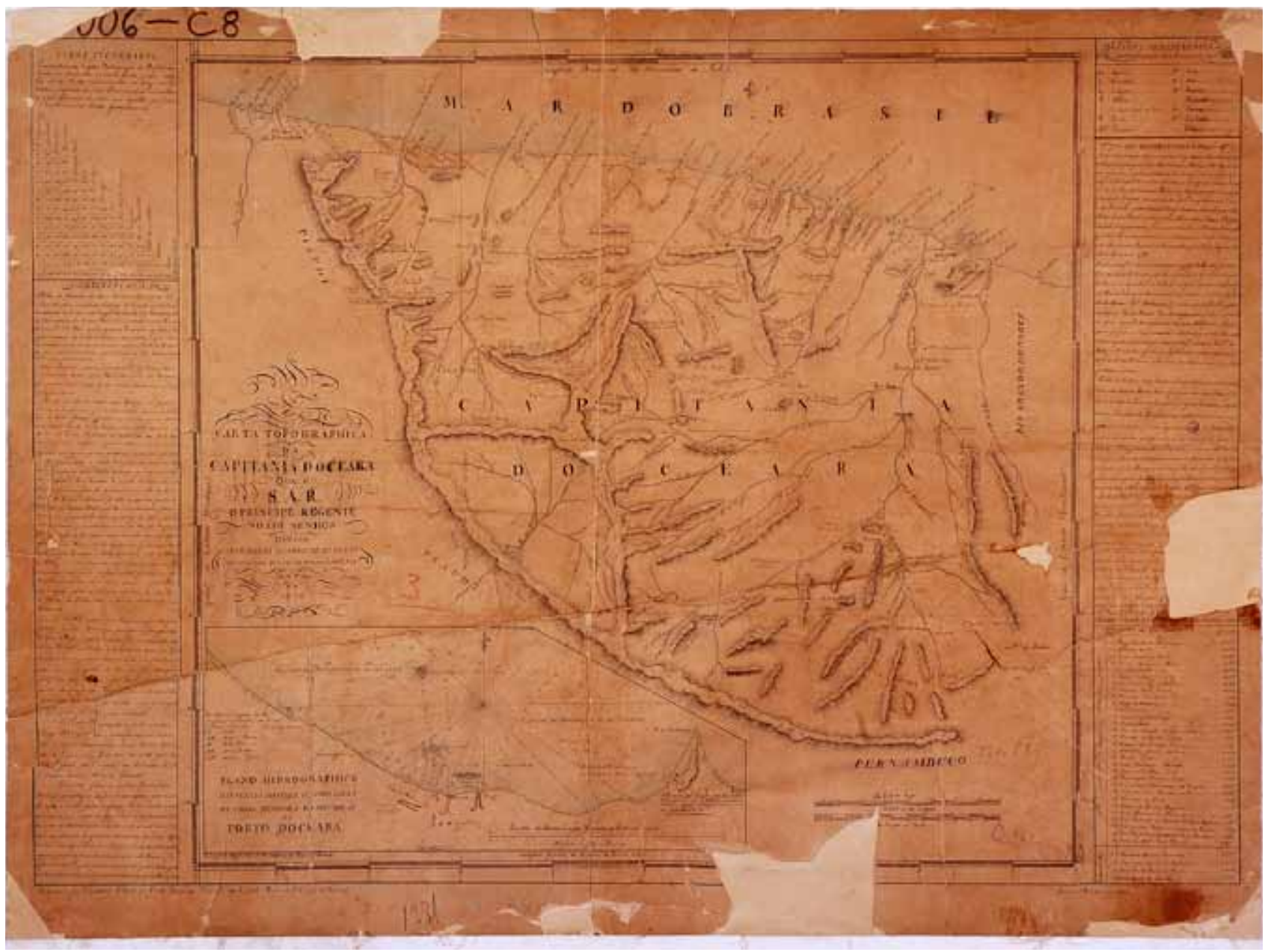

Figura 5 - Carta Topographica da Capitania do Ceará..., 1812. Acervo do Arquivo Histórico do Exército. Rio de Janeiro. 
b. Um conjunto de observações sobre a situação do porto da vila de Fortaleza. Segundo Liberal de Castro, a "Descripção" de João da Silva Feijó da zona portuária da vila apoiou-se em palavras do capitão F. A. Marques Giraldes. De acordo com o relato, a enseada de Jacareganga

he preferível á de Mucuripe porque o seu fundo é todo limpo, e porque fica a sotavento dos outros Recifes; a toda e qualquer hora as Embarcações se podem fazer á vela, e fundiar [Ela está] mais abrigada do mar, porque este quebra por cima dos Recifes e por tanto perde nelles parte de sua força ${ }^{82}$.

Ainda segundo a Descripção, o governador Luiz Barba Alardo de Menezes, em setembro de 1810, ordenara a Francisco Antonio Marques Giraldes, capitão de fragata da Armada Real, a execução geodésica do Plano Hydrographico do porto. Entre suas vantagens em relação aos outros portos do Brasil, está o encurtamento das viagens para a Europa,

em razão de soprarem os Ventos constantemente de Nordeste para Leste, de não se encontrarem na derrota [i. e. na rota] as grandes calmarias de leste [...] também a vantagem de não ser necessário tanta cautela na Navegação, por se não encontrarem durante ella Baixos, de ser de fácil reconhecimento, pelas montanhas q mui de longe se avistão a barlavento, com especialidade pela P. [ponta?] groça de Mocoripe ${ }^{83}$.

c. "Taboa de referencia" explicando "as abreviaturas empregadas no texto ('Br. Barra; E. Enceada ... P. Prezidio ou vigia do Mar; Sr. Serra')" 84 e outras.

d. Observações sobre a história da capitania, como a sua população, na ordem de 130396 habitantes.

e. Uma relação cronológica - a "Taboa Chronologica dos governadores que tem tido esta capitania" - com o nome de todos os governadores da capitania do Ceará até aquela data.

Em ofício dirigido a João Rodrigues, secretário de Estado dos Negócios da Marinha e Ultramar, no dia 13 de Dezembro de 1800, Feijó ${ }^{85}$ revelou as dificuldades encontradas na elaboração de seus trabalhos em seu primeiro ano no Ceará. Reclamou a presença de um "Desenhador capaz que à vista dos objectos vivos, os retratem como forem naturalmente", a falta de instrumentos para observações "físicas, chimicas e topográficas", de um exemplar da mais nova edição do "Sistema Geral de Lineo e da Encyclopedia methodica botânica de LaMarck e Fabrício", de uma prensa e papeis para dessecação das plantas, de um "oitante regular" para a carta topográfica onde elaborava as latitudes em que se encontravam as minas e os portos, um "grafometro e compassos mathematicos para mediar as alturas das montanhas", e um "barômetro", dentre outros instrumentos.
82. João da Silva Feijó, apud José Liberal de Castro (1997, p. 29).

83. Idem, p. 30.

84. Idem, ibidem.

85. AHU_ACL_CU_017, Cx, 14, D. 811.Arquivo Histórico Ultramarino, Lisboa. Reprodução do Projeto Resgate. 
86. Sobre Paulet, ver Guilherme Ch.Studart (1923, p. 278279); e Francisco Marques de Souza Viterbo (1998, v. 2, p. 242).

87. Cf. José Liberal de Castro, (1994,p.61-63).

88. Idem, p. 61.

89. Ver 18 de agosto de 1812. Arquivo Público do Estado do Ceará (Apec). A documentação setecentista estabelece como limite leste da capitania do Ceará a barra do Mossoró, no atual estado do Rio Grande do Norte.

90. Idem.
Não foi possível saber se suas exigências foram integralmente atendidas. Contudo, algumas suposições sobre as atividades cartográficas do naturalista podem ser levantadas. De início: o primeiro artigo- Da Corographia do Ceará, de sua Memória sobre a Capitania do Ceará, nos faz supor que Feijó percorreu todo o território cearense. Segundo: ao reclamar a presença de um "Desenhador", supomos que o naturalista não era um hábil desenhista. Terceiro: que o Naturalista, pelo menos no início de seus trabalhos, não possuía instrumentos capazes de desenhar com rigor a região. Como sabemos, em sua primeira carta (topográfica), a capitania cearense foi desenhada com uma forma alterada, "achatada", principalmente na região sul. Por fim, o primeiro mapa da capitania do Ceará desenhado por Feijó - a carta da Capitania do Ceará; dividida pelo Campo Illuminado de cor serviu de base para todos os demais elaborados por ele.

O desenho da capitania só veio a adquirir contornos que se aproximam de sua atual configuração territorial com a cartografia elaborada pelo engenheiro Antonio José da Silva Paulet86, que chegou ao Ceará em 1812, como ajudante de ordens de Manoel Ignácio de Sampaio, o último governador da capitania cearense. $\bigcirc$ engenheiro não apenas cartografou o território em suas minúcias, como elaborou uma planta para a vila da Fortaleza, com ruas entrecortadas em ângulos retos, um projeto para o edifício do mercado da vila e outro para a Fortaleza de Nossa Senhora da Assunção ${ }^{87}$.

Os trabalhos de arquitetura, urbanismo e de documentação gráfica desenvolvidos por Paulet indicam o "início de uma nova etapa de desenvolvimento material" do Ceará 88 , expressando sua autonomia políitica em relação à capitania de Pernambuco.

Em 18 de Agosto de 1812, o governador da capitania autônoma Manoel Ignácio de Sampaio dirigiu a Silva Paulet um ofício, encarregando-o de levantar a costa leste da capitania, desde a "barra do Mossoró ate a da Vila da Fortaleza" 89 . Afirmava que até então ainda não se havia determinado de "maneira positiva a posição geográfica da costa" cearense; razão porque encarregava-o de desenhar "com sufficiente exactidão".

O engenheiro Silva Paulet deveria, segundo Sampaio, "fazer não só todas as observações, que forem tendentes a perfeição da mesma Carta, mas também todas as mais que julgar úteis para o conhecimento desta Capitania". Deveria apontar a posição exała dos rios, dos lagamares, dos lugares aonde entrava a maré e se formava o sal, anotar sobre a sua manufatura e exportação; a posição, o estado e o melhoramento das estradas; o estado dos presídios da costa; e levantar todas as "indagações" que julgasse necessárias "para o conhecimento estatístico" do Ceará. Outro objetivo da nova cartografia seria o estabelecimento das "mais exactas informações" dos limites do território desde a barra do Mossoró "até o districto do Jiqui e catinga de Góes"90.

O resultado final foi a Carta da Capitania do Ceará e costa correspondente levantada por ordem do Governador Manoel lgnácio de Sampaio, pelo seu Ajudante de ordens Antonio Jozé da Silva Paulet no Anno de 18 13 , que traz em detalhe, no seu canto esquerdo, a Planta do Porto e Villa do Aracati (ver 
Figura 2) e uma Planta do Porto e Villa da Fortaleza. Nesta Carta, a capitania do Ceará já apresenta desenho similar ao do atual território do estado cearense. Contudo, as informações se limitam à costa. Os limites do sertão confundem-se com as serras de Uruburetama e Meruoca. São representadas as vilas litorâneas e aquelas que se encontram a cerca de 200 quilômetros do litoral, como a vila de Sobral.

Em ofício de 6 Abril de 1816, o governador Manoel Ignacio de Sampaio comunicou a Paulet que havia remetido "a Carta Marinha da Costa" da capitania para o secretário de Estado dos Negócios Estrangeiros e da Guerra, Marques de Aguiar. Explicitava que o mapa havia sido realizado com extrema "exactidão, justesa" e perfeição, decorrente das "observações e trabalhos trigonométricos" realizados 91 .

Em outro ofício, naquela mesma data, este dirigido ao ministro Aguiar, - governador Sampaio declarou que tanto a Carta Marítima da Costa da capitania, como a planta do porto de Fortaleza e do porto do Aracaty foram levantadas pelo engenheiro Paulet, seguindo o "methodo trigonométrico astronomico, o mais adequado as circunstâncias"92.

No dia seguinte, Manoel lgnácio de Sampaio voltou a pronunciar-se, requerendo a Paulet a elaboração de uma "Carta Geográfica"93 não restrita ao litoral, que apresentasse os limites geográficos do restante da capitania.

A Carta Marítima, e Geographica da Capitania do Ceará. Levantada por ordem do Gover Manoel lgn ${ }^{c o}$. de Sampayo por seu ajudante d'ordens Antonio Joze da Sa. Paulet, de 1817 (Figura 6), apresenta em seu canto direito uma cópia da Planta do Porto e Villa da Fortaleza ainda mais esquemática que a representada em 1813. Mostra com extremo rigor não apenas a hidrografia e a topografia, mas também a definição de suas fronteiras, a rede urbana dezessete vilas ${ }^{94}$ e mais de cinquenta povoados interligada por estradas, e a delimitação dos termos da capitania $^{95}$.

São representadas as vilas de Aquiraz, Fortaleza, Icó, Aracati, Sobral, Granja, Campo Maior, São Bernardo das Russas, São João do Príncipe, Crato, Jardim, Soure, Messejana, Arronches, Monte-mor o Novo e Vila Nova d'[El] Rey. Os povoados representados foram o seguintes: Cascavel, Monte-mor o Velho, Guaiúba, Maranguape, Siupe, Itans, Canindé, Santa Cruz, Trairi, São José, São Bento d'Amontada, Santa Quiteria, Boa Vista, Beruoca, Santo Antonio, São Benedito, Ibuassú, Baiapina, Irapá, São Gonçalo, Boa Viagem, Santa Rita, Mombaça, Quixadá, Barra do Sitiá, Livramento, São João, Tabuleiro d'Areia, Frade, Santa Rosa, Queixossó, Santo Antonio, São Cosme e Damião, Saco da Orelha, Telha, Poço do Mato, São Vicente das Lavras, Umari, São Mateus, Flores, Arneirós, Cocossi, Cruz, Brejo Grande, Barbalha, Missão Velha, Milagres, Santa Rosa, Porteiras, Córrego do Ramalho, Caatinga do Goes, Jiqui, Montamba, Almofala, Barra do Acaraú e Pará.

Analisando essa carta e a Descripção Geográfica Abreviada da Capitania do Ceará, de 1816 (1898), do engenheiro Antonio José da Silva Paulet96, sabemos que, da vila de Aquiraz, seguiam três estradas. Uma saía em
91. Ver 6 de Abril de 1816. Arquivo Público do Estado do Ceará (Apec)

92. Este outro ofício de 6 de Abril de 1816 se encontra transcrito em João Baptista Perdigão de Oliveira (1937, p. 207).

93. Ver 7 de Abril de 1816 Arquivo Público do Estado do Ceará (Apec).

94. Foram demarcados os lugares das vilas de Aquiraz, Fortaleza, Icó,Aracati, Sobral, Granja, Campo Maior, São Bernardo das Russas, São João do Príncipe, Crato, Jardim, Soure (Caucaia), Messejana,Arronches (Parangaba), Viçosa e Monte-mor o Novo (Baturité).

95. Cf. Clóvis Ramiro Jucá Neto (2007, p. 255)

96. Publicada em Antonio José da Silva Paulet (1898). 


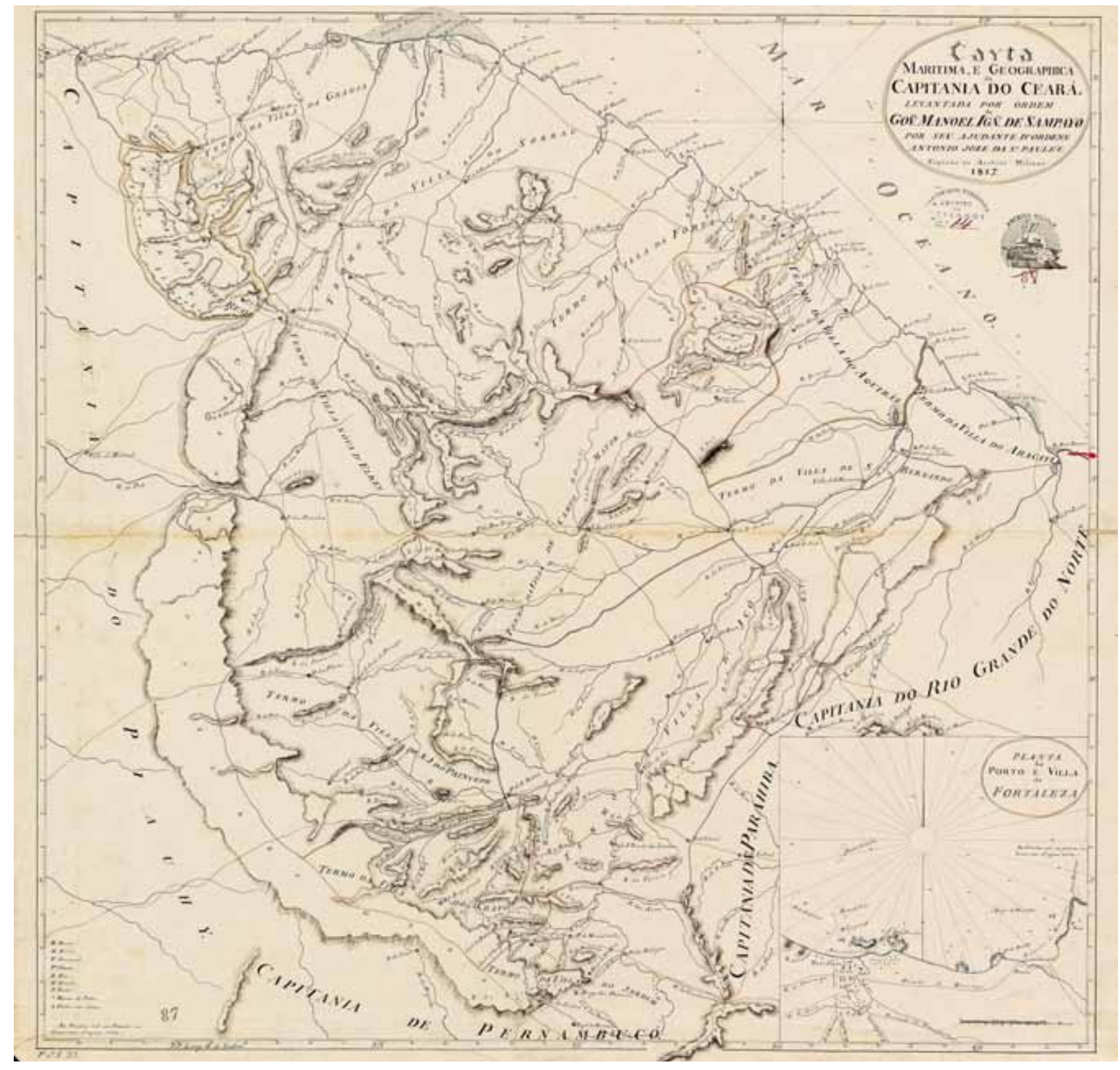

Figura 6 - Antonio José da Silva Paulet. Carta Marítima e Geográfica da Capitania do Ceará..., 1817 Fonte: Gabinete de Estudo Arqueológicos de Engenharia Militar (Geaem), Lisboa.

direção a Fortaleza, outra em direção ao Aracati e a terceira seguia no rumo da vila de Campo Maior, subindo o rio Xoró e o Pirangi, passando pela vila de Monte-mor o Novo d'América e pela povoação de Queixada. De Fortaleza, saía a estrada geral - a Estrada Velha de Capistrano de Abreu -, à beira mar, passando pela vila de Messejana, pela vila de Aquiraz, pelo povoado de Cascavel, pela vila do Aracati e pelo povoado de Montamba em direção às 
capitanias do Rio Grande do Norte e Pernambuco. Saía também a estrada para a vila do Soure, seguindo em direção a Sobral, Granja, Parnaíba e alcançando - Maranhão. Outra estrada seguia em direção ao Canindé; e mais uma em direção à vila de Monte-mor o Novo d'América, passando pela povoação de Guaiúba. Uma última ligava a vila da Fortaleza à vila de Arronches.

Por Aracati passava a estrada que vinha de Fortaleza em direção ao Rio Grande do Norte - a antiga Estrada Velha - e partia uma segunda em direção ao lcó - antiga Estrada Geral do Jaguaribe - passando pela vila das Russas, pela povoação de São João e de Santa Rosa. Já sabemos que o lcó acha-se no cruzamento da Estrada Geral do Jaguaribe com a Estrada das Boiadas. Do Icó, a primeira seguia na direção do povoado de São Vicente das Lavras e do povoado de Missão Velha, já no Cariri. De Sobral, partiam duas estradas para Fortaleza. Uma, "larga e plana", seguia pelo norte da serra de Uruburetama, passando pela povoação de São Bento d'Amontada, e outra cruzava a serra, atravessando o povoado da Cruz. Ambas se uniam nas proximidades do rio Curu, e seguiam para a vila do Soure e Fortaleza. Esta é a mesma que saía de Fortaleza passando pelo Soure em direção a Sobral. Outra estrada descia o rio Acaraú, alcançando o povoado da barra do Acaraú. Mais uma comunicava Sobral com a vila de Granja e em seguida com o Piauí. Para o Piauí, também se podia ir de Sobral pelas estradas que cruzavam a Vila de Viçosa Real e a Vila Nova d'El Rey. Esta vila estava diretamente ligada à vila de Marvão na capitania piaviense. Também de Sobral, alcançava-se a capitania de Pernambuco pelo interior, através de uma estrada "incomoda [] e deshabitada" que passava pelos povoados de Boa Vista, de Santa Quitéria e pela vila de Campo Maior - a Estrada Nova das Boiadas. Todas as demais vilas também se achavam conectadas pelas estradas cearenses.

Constatamos, ainda, que a capitania se achava dividida em 14 termos, correspondentes a cada vila criada. $\bigcirc$ maior termo era o da Vila do Sobral, seguido pelos da Vila de Icó, da Vila de Campo Maior, da Vila de São João do Príncipe, da Vila de Fortaleza, da Vila de São Bernardo, da Vila de Granja, da Vila Nova D’El Rey, da Vila do Jardim, da Vila de Aquiraz, da Vila do Crato, da Vila de Viçosa Real, da Vila de Monte-mor o Novo d'América e, por fim, pelo da Vila do Aracati.

Em 12 de junho de 181897 , o governador Manoel Ignacio de Sampaio escreveu um ofício louvando a prontidão com que Paulet havia elaborado a Carta Geográfica do Ceará, a despeito das dificuldades encontradas. Elogiou a "exactidão" com que havia sido desenhada a Carta e apresentou a possibilidade, afiançada pela Coroa portuguesa, de Silva Paulet elaborar uma Carta Geral de todo o Brasil adotando o "Methodo" empregado. 
98. Tendo como objeto de análise as práticas de nobilitação e distinção social desenvolvidas pelos membros da elite da Vila de Santa Cruz do Aracati, Gabriel Parente Nogueira apresenta um amplo quadro da rede de consensos e intrigas entre os primeiros proprietários de terra, os comerciantes, os charqueadores no vale do rio Jaguaribe, mais especificamente na região doAracati; ver Gabriel Parente Nogueira (2010).

\section{espaço como síntese de múltiplas ações}

Os vaqueiros e boiadeiros não foram apenas os primeiros desbravadores, mas os futuros sesmeiros, proprietários de terras e das fazendas de gado, e, em alguns casos, futuros representantes do Estado português no território cearense. Eles se estabeleceram às margens dos rios, onde o mínimo de pastagem para as boiadas era possível. Junto com os fazendeiros, os representantes da lgreja chegam ao Ceará ou fixando-se nos efêmeros aldeamentos ou como párocos itinerantes que, de capela em capela, difundiram os princípios contrarreformistas, sempre procurando apaziguar a população indígena, que resistia ao avanço da atividade criatória. Mas os representantes da lgreja não cumpriram apenas um papel catequético: muitos religiosos tornaram-se ainda proprietários de terra, donos de boiadas e construíram suas próprias fazendas de gado. Por quase todo o século XVIII, a lgreja esteve, também, intimamente associada ao Estado lusitano, dando suporte ideológico à conquista. $\bigcirc$ Estado, ao fixar-se no território cearense, elegeu lugares estratégicos onde outrora havia as primeiras fazendas e a lgreja já havia se implantado - para uma melhor capitalização da economia pecuarista. Na maioria das vezes, o lugar da vila fundada durante o século XVIII pelos lusitanos já fora o lugar de uma fazenda de gado ou de uma pequena ermida. Somente após sua emancipação política em relação à capitania de Pernambuco fora a capitania cartografada pelos engenheiros do Reino e por um padre Visitador. A rede urbana, do início do século XIX, seguiu os caminhos naturais do sertão, trilhados primeiramente pela população indígena, mas também pelos vaqueiros, pelos representantes da lgreja e, por fim, pelo próprio Estado português. A conquista e a fixação foram pautadas por uma rede de consensos e intrigas ${ }^{98}$. Os diversos agentes uniram-se das mais diversas formas e em tempos diferenciados, transformando o espaço. Alternam-se Estado e Igreja, Igreja e fazendeiros, fazendeiros e Estado, o Estado e os índios, marcando suas presenças no território, alterando lentamente, por todo o século XVIII, a paisagem natural do sertão e do litoral do Ceará.

\section{REFERÊNCIAS}

\section{FONTES ICONOGRÁFICAS E MANUSCRITAS}

Arquivo Histórico Ultramarino, Lisboa

Projeto Resgate

Documentos Avulsos da capitania do Ceará e Documentos Avulsos da capitania de Pernambuco

AHU_ACL_CU_015.Cx. 55. D. 4767. CARTA de Henrique Luís Pereira Freire de Andrada, governador da capitania de Pernambuco, ao rei D. João V, escrita do Recife em 10 de dezembro de 1739. 
AHU_ACL_CU_015.Cx. 126. D.9545. CARTA do Bispo de Pernambuco D. Tomás [da Encarnação Costa e Lima] ao rei [D. José I] remetendo uma relação de todas as freguesias, capelas, remidas e orários que tem o dito Bispado, e o numero de clérigos seculares que existem em cada uma das freguesias.Anexos: 2 documentos. Recife, 17 de fevereiro de 1777.

AHU_ACL_CU_015.Cx. 249.D. 16728. REQUERIMENTO de Mariano Gregório do Amaral escreveu ao príncipe regente D. João, para que José Maria de Araujo, bispo eleito de Pernambuco o aceitasse para a Cadeira de Desenho no Seminário Episcopal, [anterior a] 28 de julho 1804.

AHU_ACL_CU_017.Cx.9.D.564.CARTA do ouvidor do Ceará José da Costa Dias Barros à Rainha, de 25 de junho de 1779 .

AHU_ACL_CU_017,Cx. 12, D. 693. CARTA de Manuel da Cunha Pereira, capitão comandante da Ribeira do Jaguaribe pedindo licença à rainha $\mathrm{D}$. Maria I para edificar uma ermida em homenagem a Nossa Senhora das Dores, na Fazenda Boqueirão, freguesia das Russas. ca. 1793.

AHU_ACL_CU_017.Cx. 14.D.811.OFÍCIO de João da Silva Feijó dirigido a João Rodrigues, secretário de Estado dos Negócios da Marinha e Ultramar,de 13 de Dezembro de 1800.

\section{Arquivo Histórico do Exército, Rio de Janeiro}

BLOEM, João. Planta da Barra e rio de Jaguaribe elaborada em 1825, pelo Capitão do Imperial Corpo de Engenbeiro João Bloem [Detalhe: Planta do Aracati].Arquivo Histórico do Exército_RJ_Série Nordeste_Sub-Série Ceará_Localização 02.04.335.

FEIJÓ, João da Silva [atrib.]. Capitania do Ceará; Dividida/pelo Campo Illuminado de cor.Arquivo Histórico do Exército_RJ_Série Nordeste_Sub-Série Ceará_Localização 02.04.362.

FEIJÓ, João da Silva [atrib.]. Carta Topographica / da / Capitania do Ceará / que a / SAR / o Príncipe Regente / Nosso Senhor / Dedica / Luiz Barba Alardo de Menezes/ no ano de 1812. Arquivo Histórico do Exército_RJ_Série Nordeste_Sub-Série Ceará_Localização 02.04.364.

\section{Arquivo Público do Estado do Ceará (Apec), Fortaleza}

18 de agosto de 1812. OFICIO dirigido ao tenente Coronel Engenheiro Antonio Joze da S.a Paulet encarregando-o de levantar a planta da costa desde a barra do Mossoró ate a da V.a da Fortaleza. Livro 33 (Antigo 65-A). Ala 02. Estante 03. Prateleira 14. Caixa 10. Série: Governo da Capitania do Ceará aos militares da Capitania, ofícios. Data crônica-1812.

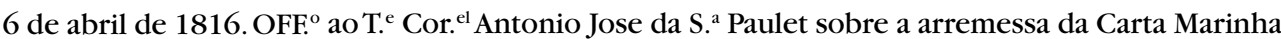
da Costa desta Capitania p. ${ }^{a}$ a Secretaria de Estado dos Neg. ${ }^{\text {os }}$ Estrangeiros, e da Guerra. Livro 35 (Antigo 89). Ala 02. Estante 03. Prateleira 14. Caixa 10. Série: Governo da Capitania do Ceará aos militares da Capitania, ofícios. Data crônica: 1814-1815.

7 de abril de 1816. OFF $^{\circ}$ ao tenente Coronel Antonio Jose da Silva Paulet para levantar a Carta geográfica da Capitania. Livro 35 (Antigo 89). Ala 02. Estante 03. Prateleira 14. Caixa 10. Série: Governo da Capitania do Ceará aos militares da Capitania, ofícios. Data crônica: 1814-1815.

12 de junho de 1818 . OFF ${ }^{\circ}$ ao Ten ${ }^{\text {te }} \mathrm{C}^{\text {el }}$ Paulet louvando a boa promptidão com q'. levantou a Carta Geografica. Livro 38 (Antigo s. número). Ala 02. Estante 03. Prateleira 14. Caixa 11. Série: Governo da Capitania do Ceará aos militares da Capitania, ofícios. Data crônica: 1814-1815. 
FREIRE ALEMÃO, Francisco. Manuscritos. Anaes da Biblioteca Nacional.

[O índice e catálogo desses manuscritos está publicado em DAMASCENO, Darcy; CUNHA, Waldir da (Cat. e Transcr.). Os Manuscritos do botânico Freire Alemão. Anais da Biblioteca Nacional, Rio de Janeiro, v. 81, 1961. Disponível em: <http://objdigital.bn.br/acervo_digital/anais/ anais_081_1961.pdf>].

\section{GABINETE DE ESTUDOS ARQUEOLÓGICOS DE ENGENHARIA MILITAR (GEAEM), LISBOA}

PAULET,Antonio José da Silva. Carta Marítima e Geográfica da Capitania do Ceará. Levantada por ordem do Gov ${ }^{o r}$ Manoel Ignácio de Sampayo por seu ajudante d'ordens Antonio Joze da $S^{a}$ Paulet. 1817. Desenho n. 4578.

\section{MAPOTECA DO ITAMARATY / MINISTÉRIO DAS RELAÇÕES EXTERIORES, RIO DE JANEIRO}

PAULET,Antonio José da Silva. Carta da / Capitania do Ceará e costa / correspondente levantada por / ordem do Governador Manoel / Ignácio de Sampaio, pelo seu / Ajudante de ordens Antonio / Jozé da Silva Paulet no / Anno de 1813 [detalhe: Planta do Aracati].

\section{LIVROS, ARTIGOS E TESES}

ABREU, João Capistrano de. Capítulos de história colonial: 1500-1800 \& Os caminhos antigos e o povoamento do Brasil. 2. ed. Brasília: Editora Universidade de Brasília, 1998.

ALVES, Joaquim. História das Secas (séculos XVII-XIX). Fortaleza: Fundação Waldemar Alcântara, 2003. Edição fac-similar (1953) (Biblioteca Básica Cearense).

ARAÚJO, Padre Francisco Sadoc de. Cronologia Sobralense (1801-1804), 2. Fortaleza: GEC, 1979.

ARAÚJO, Renata K. Malcher de. As cidades da Amazônia no século XVIII: Belém, Macapá e Mazagão. Porto: Faup, 1998.

A urbanização do Mato Grosso no século XVIII. Discurso e método, 1. 2000. Tese (Doutorado em História da Arte) - Faculdade de Ciências Sociais e Humanas da Universidade Nova de Lisboa, Lisboa, 2000.

BARRIOS, Sonia.A produção do espaço. In: SOUZA, Maria Adélia de; SANTOS, Milton (Org.). $A$ construção do espaço. Nobel: São Paulo, 1986.

BARROSO, Gustavo. À margem da bistória do Ceará. Fortaleza: Universidade Federal do Ceará, 1962.

BEZERRA, Maria do Carmo Lima. Notas sobre as casas de fazenda dos Inhamuns. 1984. Monografia (Aperfeiçoamento em Arquitetura) - Departamento de Arquitetura e Urbanismo, Centro de Tecnologia, Universidade Federal do Ceará, Fortaleza, 1984.

BUENO, Beatriz P. Dilatação dos confins: caminhos, vilas e cidades na formação da Capitania de São Paulo (1532-1822). Anais do Museu Paulista, São Paulo, v. 17, n. 2, p. 251-294, jul.-dez. 2009 [Nova Série]. 
BRAGA, Renato. Um capítulo esquecido da economia pastoril do Nordeste. Revista do Instituto do Ceará, Fortaleza, n. 61, p.149-162, 1947.

CASTRO, José Liberal de. Contribuição de Adolpho Herbster à forma urbana da cidade de Fortaleza. Revista do Instituto do Ceará, Fortaleza, n. 108, p. 43-90, 1994.

Cartografia cearense no Arquivo Histórico do Exército. Revista do Instituto do Ceará, Fortaleza, n. 111, p. 7-79, 1997.

Urbanização pombalina no Ceará: a paisagem da vila de Montemor-o-Novo d'América. Separata de: Revista do Instituto do Ceará, Fortaleza, n. 113, p. 35-81, 1999.

CORTESÃO, Jaime. Alexandre de Gusmão e o Tratado de Madrid. Lisboa: Horizonte, 1984. 4v.

COSTA, D. Rodrigo. Carta para Nicolau da Fonseca Tourinho sobre gado que se cria no termo da vila de Boipeba [30 jan. 1705]. In: MINISTÉRIO DA EDUCAÇÃO E SAÚDE (Biblioteca Nacional). Documentos Históricos: correspondência dos governadores gerais, 1704-1714, 40. Rio de Janeiro: Typ. Baptista de Souza, 1938. p. 306. Disponível em: <http://memoria.bn.br/rmhb/_pdf/094536/ per094536_040.pdf>.

FONSECA, Cláudia Damasceno.As vilas e os territórios: processos de formação e evolução da rede urbana na capitania de Minas Gerais. In:ARAUJO, Renata; CARITA, Helder; ROSSA, Walter (Coord.). Actas do Colóquio Internacional Universo Urbanístico Português, 1415-1822. Lisboa: CNCDP, 2001.p. 769-785.

FROTA, D. José Tupinambá da. História de Sobral.3. ed. Fortaleza: Imprensa Oficial do Ceará; Henriqueta Galeno, 1995.

GARDNER, George. Viagem ao Interior do Brasil, principalmente nas províncias do Norte e nos distritos do ouro e do diamante durante os anos de 1836-1841. Belo Horizonte: Itatiaia; São Paulo: Edusp, 1975.

GIRÃO, Raimundo. Pequena História do Ceará. 2. ed. Fortaleza: Instituto do Ceará, 1962.

Evolução histórica cearense. Fortaleza: BNB; Etene, 1985 (Documentos do Nordeste 5).

—. História Econômica do Ceará. 2. ed. Fortaleza: Casa José de Alencar; Programa Editorial, 2000.

GOULART, José Alípio.A Formação da zona da pecuária nordestina. Revista do Instituto Histórico e Geográfico Brasileiro, Rio de Janeiro, n. 259, p. 16-26, 1963.

Brasil do boi e do couro: o boi, 1. Rio de Janeiro: GRB, 1965 (Ensaios Brasileiros).

JUCÁ NETO, Clovis Ramiro. A urbanização do Ceará setecentista. As vilas de Nossa Senhora da Expectação do Icó e de Santa Cruz do Aracati. 2007. Tese (Doutorado em Arquitetura e Urbanismo) - Universidade Federal da Bahia, Salvador, 2007.

Desenhando o Ceará. In: SIMPÓSIO IBERO-AMERICANO DE HISTÓRIA DA CARTOGRAFIA, 3. Agendas para a História da Cartografia Ibero-americana. Comunicação livre. Universidade de São Paulo, 26-30 abr. 2010, São Paulo.

KOSTER, Henry. Viagens do Brasil.Trad. Luis da Câmara Cascudo. 12. ed. Rio:ABC, 2003.

Annals of Museu Paulista. v. 20. n.1. Jan.-Jun. 2012. 
LEMENHE, Maria Auxiliadora. As razões de uma cidade: conflito de hegemonias. Fortaleza: Stylus, 1991.

MARX, Murillo. Cidade no Brasil: terra de quem? São Paulo: Edusp; Nobel, 1991.

MENEZES,Antonio Bezerra de.Algumas origens do Ceará. Revista do Instituto do Ceará, Fortaleza, n. 15, 1901.

MORAES, Antonio Carlos Robert. Bases da formação territorial do Brasil: o território colonial brasileiro no "longo" século XVI. São Paulo: Hucitec, 2000 (Estudos Históricos, 41).

MOTA, Aroldo C. Município de Tauá: origem. Revista do Instituto do Ceará, Fortaleza, n. 115, p. 111-126, 2001

NOBRE, Geraldo da Silva. As oficinas de carnes do Ceará: uma solução local para uma pecuária em crise. Fortaleza: GEC, 1977.

História eclesiástica do Ceará, 1. Fortaleza: Secretaria de Cultura e Desportos, 1980.

. Formação das Cidades no Ceará-Colônia. Revista do Instituto do Ceará, Fortaleza, n. 100, p. 241-254, 1986.

NOGUEIRA, Gabriel Parente. Fazer-se nobre nas fímbrias do Império: práticas de nobilitação e hierarquia social da elite camarária de Santa Cruz do Aracati (1748 - 1804). 2010. Dissertação (Mestrado em História Social) - Universidade Federal do Ceará, Fortaleza, 2010.

NOGUEIRA, Paulino. O naturalista João da Silva Feijó. Revista do Instituto do Ceará, Fortaleza, n. 2, p. 247-276, 1888.

OLIVEIRA, João Baptista Perdigão de. A vila de Quixeramobim. Revista do Instituto do Ceará, Fortaleza, n. 4, p. 273-296, 1890.

. O Ceará e seus limites. Revista do Instituto do Ceará, Fortaleza, n. 51, p. 201-245, 1937.

PAULET,Antonio José da Silva. Descripção geográfica abreviada da capitania do Ceará. Revista do Instituto do Ceará, Fortaleza, n. 12, p. 5-33, 1898.

PINHEIRO, Francisco José. Notas sobre a formação social do Ceará (1680-1820). Fortaleza, Fundação Ana Lima, 2008.

PUNTONI, Pedro. A guerra dos bárbaros: povos indígenas e a colonização do sertão nordestino do Brasil, 1650-1720. São Paulo: Hucitec; Edusp; Fapesp, 2002 (Estudos Históricos, 44).

REIS FILHO, Nestor Goulart. Contribuição ao estudo da evolução urbana do Brasil (15001720). São Paulo: Pioneira; Edusp, 1968.

REGISTRO dos autos da erecção da real villa de Monte-mór o Novo da América, na capitania do Ceará Grande. In: Revista do Instituto do Ceará, Fortaleza. n. 5, p. 265-300, 1891.

ROCHA, Limério Moreira da. Russas: 200 anos de emancipação política. Fortaleza: Banco do Nordeste, 2001.

ROSSA, Walter.A Cidade Portuguesa. In: . A urbe e o traço. Uma década de estudos sobre o urbanismo português. Coimbra:Almedina, 2002. 
SANTOS, Milton. A natureza do espaço: espaço e tempo, razão e emoção. 3. ed. São Paulo: Hucitec, 1999.

SANTOS, Paulo F. Formação de cidades no Brasil colonial. In: Separata de COLÓQUIO INTERNACIONAL DE ESTUDOS LUSO-BRASILEIROS, 5.Actas... Universidade de Coimbra, 1968 [SANTOS, Paulo. Formação de cidades no Brasil colonial. Rio de Janeiro: Editora UFRJ, 2001].

SIMONSEN, Roberto C. História econômica do Brasil: 1500/1820. 10. ed. São Paulo: Nacional, 1978 (Brasiliana, 5).

LEITE, Padre Serafim Soares, S. J.História da Companbia de Jesus no Brasil (séculos XVII-XVIII), 3. Rio de Janeiro: Instituto Nacional do Livro. 1943.

STUDART, Guilherme Ch. Barão de. Notas para a bistória do Ceará (Segunda metade do século XVIII). Lisboa:Typographia do Recreio, 1892.

Geografia do Ceará. In: Revista do Instituto do Ceará, Fortaleza, n. 37, p. 169-384, 1923.

STUDART, Barão de. Datas e factos para a bistória do Ceará./Barão de Studart. Edição fac-sim.Fortaleza: Fundação Waldemar Alcântara, 2001. 526p. Tomo I (Col. Biblioteca Básica Cearense). Fac-Símile - edição de 1896.(Assim encontra-se na ficha catalográfica da publicação)

STUDART FILHO, Carlos. Resistência dos indígenas à conquista e povoamento da terra: a "Guerra dos Bárbaros" [1]. Revista do Instituto do Ceará, Fortaleza, n. 73, p. 29-70, 1959.

. Resistência dos indígenas à conquista e povoamento da terra: a "Guerra dos Bárbaros" [2] Revista do Instituto do Ceará, Fortaleza, n. 75, p. 163-208, 1961.

VASCONCELOS, Sylvio de. Sistemas construtivos adotados na arquitetura do Brasil. [Apostila das disciplinas de História da Arquitetura e Evolução Urbana III]. Fortaleza: Faculdade de Artes e Arquitetura da Universidade Federal do Ceará, 1970.

VITERBO, Francisco Marques de Souza. Dicionário bistórico e documental dos architectos, engenbeiros e construtores portugueses, 1-3. Pref. Pedro Dias. Lisboa: Imprensa Nacional-Casa da Moeda, 1998. Edição fac-similar (1899). 3v.

Artigo apresentado em 1/2011. Aprovado em 12/2011.

Annals of Museu Paulista. v. 20. n.1. Jan.-Jun. 2012. 